\title{
Integration of Sustainability into Architectural Education at Accredited Korean Universities
}

\author{
Sun-Young Rieh ${ }^{1, *}$, Byung-Yun Lee ${ }^{2, *}$, Joon-Gul Oh ${ }^{3, *}$, Thorsten Schuetze ${ }^{4, *}$, \\ Santiago Porras Álvarez ${ }^{5, *}$, Kyungsun Lee ${ }^{6}$ and Jiyoung Park ${ }^{7}$ \\ 1 Department of Architecture, University of Seoul, 163 Seoulsiripdae-ro, Dongdaemun-gu, \\ Seoul 130-743, Korea \\ 2 Department of Architecture, Chungbuk National University, 1 Chungadae-ro, Seowon-Gu, Cheongju, \\ Chungbuk 28644, Korea \\ 3 Department of Architecture, Seoul National University of Science \& Technology, 232 Gongneung-ro, \\ Nowon-gu, Seoul 01811, Korea \\ 4 Department of Architecture, SungKyunKwan University, 2066 Seobu-ro Jangan-gu, Suwon-si, \\ Gyeonggi-do 440-746, Korea \\ 5 Department of Architecture, Korea University, 145 Anam-ro, Seongbuk-gu, Seoul 136-713, Korea \\ 6 School of Architecture, Hongik University, Wausan-ro, Mapo-gu, Seoul 121-791, Korea; \\ ksunlee01@gmail.com \\ 7 Department of Architecture, Inha University, 100 Inharo, Nam-gu, Incheon 402-751, Korea; \\ jypark@inha.ac.kr \\ * Correspondence: syrieh@uos.ac.kr (S.-Y.R.); ecoville@chungbuk.ac.kr (B.-Y.L.); \\ jgoh@seoultech.ac.kr (J.-G.O.); t.schuetze@skku.edu (T.S.); santiago@korea.ac.kr (S.P.Á.)
}

Received: 21 April 2017; Accepted: 19 June 2017; Published: 27 June 2017

\begin{abstract}
This paper examines the integration of sustainability principles into architectural education programs at South Korean Universities that have been accredited by the Korea Architectural Accrediting Board (KAAB). Accreditation requires the successful implementation of 30 so-called Student Performance Criteria (SPCs). Similar to recent improvements to international architectural education, different principles of sustainability have been successfully implemented by the KAAB. This paper identifies eight sustainability-related SPCs that can be utilized to teach sustainability. The analysis of 48 accredited five-year architectural education program curricula in South Korea has revealed which sustainability-related SPCs are addressed each semester. Furthermore, the average number of credits per sustainability-related SPC in different course types, such as theory courses and design studios, has been identified. Theory courses with an emphasis on sustainability education have been defined as sustainability core courses. The results reveal that a majority of existing programs primarily address environmental aspects of sustainability. Furthermore, a sequential course structure analysis elucidates three main curriculum types, with different potential for integrated sustainability education in sustainability core courses and design studios: (i) sustainability core course preceding (high potential); (ii) sustainability core courses and design studio, accompanying (high potential); and (iii) sustainability core course following (low potential).
\end{abstract}

Keywords: sustainable architecture; architectural education accreditation; integration; design studio; theory courses; curriculum \& course structure; Korea Architectural Accrediting Board (KAAB)

\section{Introduction}

Globally, sustainable development has been a challenging task that necessitates collective knowledge and effort, rather than relying on the policies and capabilities of individual countries, because sustainable development is intrinsically holistic and interconnected. Jabareen identified a conceptual framework for sustainable development that incorporates natural capital stock, equity, 
integrative management, eco-form, a global agenda and utopia [1]. Many scholars, environmentalists, and governmental officials agree that the pursuit of sustainability should consist of a balance between environmental, sociocultural and economic efforts, which ultimately contribute to equity (Figure 1) [2-6].

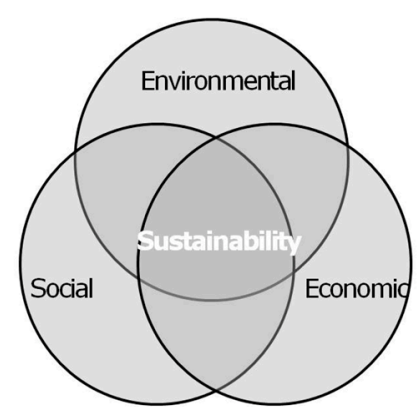

Figure 1. Venn diagram showing that sustainability consists of a balance between environmental quality (Environmental), sociocultural quality (Social), and economic quality (Economic).

Accordingly, the UNESCO/International Union of Architects (UIA) Charter for Architectural Education of 2001 recognized the importance of addressing sustainability in educational programs and, in particular, emphasized sensitivity toward the environment and social responsibility [7] (p. 5). In this context, creating sustainable architecture transcends local borders and traditional architectural practice [8] (p. 4). Globally-minded, holistic professional architectural education in sustainability will be meaningful and impactful, because the built environment is responsible for a wide range of environmental issues. For example, buildings account for more than $40 \%$ of global energy consumption and approximately one third of global greenhouse gas emissions [9].

Professionally, the quality of service offered in a global economy by a business is directly impacted by professional education standards, which are delineated by a common agreement. As such, the accreditation systems in architectural education are a core issue in educational debates, as they set minimum requirements for the curriculum and the rigor with which this content is taught. However, there is concern about accrediting bodies' regulations not doing enough, and even becoming an obstacle that confines the designer's imagination and stratagem when envisioning sustainable environments [10]; [11] (p. 21).

Even 20 years ago, a special report funded by the Carnegie Foundation in the United States criticized accrediting systems by stating that sustainable architecture should be mainstream, not a topic for a special group of professionals or a trendy set of ideas [12]. In 2012, the Sustainable Architecture Education White Paper discussed a global agenda for implementing sustainability in accredited architectural education programs (hereafter, programs). The authors pointed out the challenging task these accrediting bodies faced in order to balance normative requirements with academic freedom [13] (p. 11).

In order to better integrate sustainability and utilize both imaginative and technical skills, it is necessary to reconsider architectural education by implementing creative and sustainable design methods [13] (pp. 6-7). Most programs base their training on architectural design studios (hereafter, studios). Studios are practical courses in which students simulate a variety of design tasks that they would experience in an architectural firm. University curricula generally offer theoretical courses, which provide the necessary background and knowledge, in parallel with studios. This studio-based curriculum integrating theoretical support follows the International Union of Architects' (UIA) guidelines [14].

Proper integration is generally considered to be a desirable strategy involving optimal output [15]; [16] (pp. 26-28); [17-19]. Therefore, the value of thorough analysis and research toward 
improving sustainability-centric architectural education accrediting systems, not only in theory courses, but also in studios, cannot be over-emphasized.

For the sake of clarity it is noted that the terms integration and integrated are used throughout the text in two different contexts. The first refers to the education system, as stated in the title of this article. The second is applied to the architectural design itself, usually in the concept of integrated building or integrated design. In both contexts, the terms integration and integrated come from the verb to integrate, defined in the dictionary as "combine (one thing) with another to form a whole. [... ] from Latin integrat- 'made whole'" [20].

In the educational context, the focus of this article is how the sustainability-related contents can be combined with other contents to compose consistent and well-organized curricula, hence the term integration. Integration is used as opposed to a simple addition of sustainable contents in the curriculum, without consideration of their relation to other contents.

In the context of building design, the term integrated building or integrated design addresses the inherent complexity of the buildings. Buildings are composed of different and often conflicting parts and aspects (design intentions, different technologies and agents, legal and budgetary restrictions, etc.). A consistent architectonic design requires an integrative approach that includes all of these parts and aspects. Already in the First Century, Vitruvius stated the complex and wide variety of fields involved in the architect's work, and the need for integrating them in that work [21] (Book 1, chapter 1, paragraphs 1 and 2). By the end of the 20th Century, with new technologies and professions involved, integrated design became a specialized field of study [22]. In building design, integration is defined as "bringing all of the building components together in a sympathetic way and emphasizing the synergy of the parts without compromising the integrity of the pieces" [23] (p. 16). Some authors defend that integrated building is a synonym for green building [24] (p. 1). Without necessarily being so radical, a correct integrative approach is indeed a necessary condition to produce a sustainable building. Therefore, integrated design is an inherent part of the compulsory knowledge and abilities of architects [14]. The $\mathrm{KAAB}$, following UIA recommendations, also includes integration among the required contents of their architectural education programs [7].

The idiosyncrasy of the duality of theory courses and studios in the programs deserves a short reference to its pedagogical implications. The studio system has often been considered as a good ground for the experimentation of modern pedagogical theories, especially Problem-Based Learning (PBL). Studio and PBL have interesting common points, as minimum professor guidance, open-ended problems, individual research, collaborative work, and so on [13,25-28]. These are examples of interesting possibilities of pedagogical innovation, but still in the early stages of experimentation and not exempt from criticism [29]. Besides, the accreditation entities usually limit themselves to setting minimum standards on education, respecting the diversity and pedagogical freedom of each institution $[7,30,31]$. The discussion of specific pedagogical methodologies is beyond the scope of this paper.

However, some academic standpoint is necessary in order to suggest even minimum recommendations, without making a stance either for, or against, pedagogical innovation. Architecture as a discipline has a long tradition of a strong integration of theoretical knowledge with practical ability. Vitruvius's statement "...architects who have aimed at acquiring manual skill without scholarship have never been able to reach a position of authority to correspond to their pains, while those who relied only upon theories and scholarship were obviously hunting the shadow, not the substance", has remained a strong principle in architectural education [21] (Book 1, Chapter 1, Paragraph 2). The European Beaux-Arts continued the same principle, and today, UNESCO-UIA educational criteria keep stating the need to achieve the right balance between theory and practice in education, as the very first aim to be achieved in educational programs [30]; [32] (pp. 6, 17). This tradition is compatible with innovation, and it is interesting to note that even problem-based learning theories assume previous knowledge as a starting point for any process of problem solving [33,34]. It is from this perspective 
and according to their accumulated academic experience that the authors propose some suggestions at the end of this paper.

The development of the Korean accreditation system is related to the Canberra Accord on Architectural Education (CAAE). The CAAE was signed in 2008 in Canberra, Australia, by accrediting organizations operating in countries across Asia, Oceania, America and Africa. This event enabled these countries to realize the comparability of their accreditation systems and, therefore, the substantial equivalence of their accredited programs [35]. Substantial equivalence does not automatically afford a program accreditation; rather, it is a realization that opens the door to mutual degree recognition and professional mobility [36] (pp. 32-36). Currently, the CAAE is subscribed to by accrediting boards in the USA (NAAB, National Architectural Accrediting Board), Canada (NBAA, National Board of Architectural Accreditation), Mexico (ANPADEH, Acreditador Nacional de Programas de Arquitectura y Disciplinas del Espacio Habitable), China (NBAA, National Board of Architectural Accreditation), Australia (AIA, The Australian Institute of Architects), South Korea (KAAB, Korea Architectural Accrediting Board) and the Commonwealth (CAA, Commonwealth Association of Architects) [37].

Within the Asian-Pacific region, Korean programs are accredited exclusively by the KAAB, which was established in 2005 and joined the CAAE as a foundational member in 2008 [38]. In 2007, the KAAB gave its first three accreditations [19]. By 2017, the KAAB had accredited 54 domestic programs and two programs in Indonesia $[39,40]$. These international accreditations were recognized by CAAE members due to substantial equivalency [36,39,40]; [41] (pp. 32-36). The provision of international services reflects the influence of Korea in the Asian region and indicates the potential to integrate sustainability issues into architectural education in other Asian countries. In particular, Asian countries have experienced rapid urbanization and have had to confront the negative economic, social and environmental effects of unsustainable development. Considering the international concern for the environment and development, as well as the specific conditions of Asian countries, we cannot disregard the social and economic issues pertaining to sustainability in the global economy [42].

Especially since the 20th century, many Asian countries have followed a Westernized paradigm in architectural education and practice relating to modern urbanization [19-43]; [44] (pp. 118-119). Accordingly, there is a clear need to implement sustainable urban development practices in architectural education, with a particular emphasis on the specific circumstances in Asia.

This research reviews (and provides a methodology for reviewing) how sustainability is integrated into architectural education. As a result this research aims to contribute to improve the integration of sustainability into architectural education, particularly in Asia, using Korean universities accredited by the KAAB as case studies. The results will identify critical issues that need to be addressed, in order to improve the criteria of the current architecture accreditation system in Korea. The research also puts forth a desirable roadmap through which to more comprehensively and consistently integrate sustainability issues into Korean programs. Ideally, these results will help to successfully develop a better accreditation and evaluation system for programs in South Korea, as well as the Asian countries where the KAAB accreditation system is applied.

Section 2 discusses the integration of sustainability into architectural education through a review of existing research. Section 3 describes the criteria and procedures used to collect and analyze 48 of the $54 \mathrm{KAAB}$-accredited programs, in terms of the extent to which they integrate sustainability-related content. Six Korean programs were not included in this research, because at the time of carrying out this research, they were not (yet) accredited. The data are collected from each of the architectural program reports of the remaining 48 programs. The architectural program report is a document that contains important information about the structure and content of a program and is required by the KAAB for program accreditation [7] (p. 20). Section 4 contains a detailed analysis of the quantitative allocation and distribution of teaching credits in the curricula, with an emphasis on the different patterns of integration between studios and sustainability core courses. Section 5 discusses the findings, while Section 6 concludes by identifying critical issues and recommendations. 


\section{Integration of Sustainability into International Accredited Architectural Education}

Sustainability issues related to architectural education have been evaluated over a relatively short research period. Some early studies stressed the need for sustainability in architectural education. For example, Wright introduced the way in which sustainable design could be integrated into coursework with a clear description in the curriculum [45]. This curricular improvement helped connect theory and application between education and professional practice. In addition, Warburton introduced the concept of deep learning, which is crucial for sustainability education [46]. Given the range and interconnectedness of environmental, social and economic issues, as well as the importance of interdisciplinary thinking and holistic insight with respect to global environmental justice, deep learning is particularly relevant to sustainability education.

More practically, Kahn et al. pointed out a significant gap between academia and practice in architecture [47]. The authors suggested that sustainability should be taught as an intrinsic value of design, rethinking conventional notions of sustainability, ecology and energy, in order to create alternative conceptions in architectural education. This framework would be complemented by empirical and productive dialogues between architectural theory and practice.

From the late 2000s, comparative studies of university curricula at the regional or national level were conducted. Ostwald et al. carried out the first comprehensive study of architecture schools in Oceania using data spanning a 20-year period [48]. The authors investigated the 20 schools in Australia, New Zealand and Papua New Guinea that were accredited at the time of the research by the Australasia Association of Schools of Architecture (AASA). Since the study covered an extensive scope, sustainability education was not focused on in detail. However, the authors did discover that on average, the smallest percentage of credits was assigned to environment-related curriculum content. In nine of the 19 schools, environment-related course content was not even addressed at all. This is in contrast to the second highest importance assigned to environment-related course content (after design-related course content) according to the rating of faculty members [48] (pp. 129-134).

In Europe, Altomonte et al. coordinated the Environmental Design in University Curricula and Architectural Training in Europe (EDUCATE) Project between 2009 and 2012 [10]. This was the most extensive and detailed study we found. It focused on the implementation of sustainability education in Europe after the Bologna unification process. A total of 69 programs were reviewed in terms of the degree to which sustainability was taught and practiced in architecture and urban design. The authors also offered guidelines for curriculum development in professional education.

Subsequently, Altomonte et al. assessed the efficacy of the EDUCATE Project, in order to identify strategies to facilitate knowledge transfer between the creative and scientific disciplines at the core of sustainable architecture and urban design [49]. The paper was structured in the following three parts: the first presented the challenges in practicing sustainable design; the second elaborated on the barriers to and opportunities for promoting sustainability in higher education; and the third put forth a map for implementing sustainability education in architecture and urban design. Specific suggestions were summarized in three areas: integration of theory and studios (including innovative approaches as learning-by-doing and PBL); improvement of students' ethos and motivation; and implementation of more intensive use of information and communication technologies (including a wider use of e-courses).

Salama and Amir studied 18 programs across several Arab countries [50] and identified three paradigms comprising the current perception of sustainable architecture. These included environment-behavior studies, sustainability and environmental consciousness and digital and virtual practices. The authors also pointed out a general imbalance among these three trends and a general lack of integration between theory and studios.

Ismail et al. reviewed the integration of sustainability knowledge in the curricula of 10 schools in the U.K. and the U.S. [51]. The first part of the study compared the Architects Registration Board (ARB) in the U.K. and the National Architectural Accrediting Board (NAAB) in the U.S. The next part quantitatively analyzed courses related to sustainability at several programs in terms of the percentage 
of total courses; the ratio of theoretical to practical courses in studios and electives; and the percentage of courses by grade. The paper concluded that the approach from each school towards integrating sustainability knowledge into their curricula was very diverse; therefore, the authors could not identify any distinctive approach to integrating sustainability into the program. Alternatively, Iulo et al. focused on the curricular aspects of environmentally-conscious architectural education by evaluating six architecture programs in the U.S. [52]. The authors found four radically different approaches to sustainability education, namely core value, system-focused, choice and specialization. Ultimately, the authors proposed a five-year model through which to deliver environmentally-conscious content.

In Asia, Shari and Jaafar analyzed nine architecture schools in Malaysia, to assess how well they integrated sustainability issues into their programs [53]. They conducted a quantitative analysis of the curricula and a qualitative analysis of a survey and concluded that it would be difficult to properly implement sustainable programs using the existing curricula. Thus, the authors provided some basic recommendations to gradually transition to a more environmentally-conscious curriculum. In 2002, Rieh analyzed twenty studios in major South Korean schools, with a focus on international architectural education standards. The study found that sustainability principles were insufficiently implemented in studios, and when they were presented, the content was strongly biased toward technology [54].

Ten years later, Lee et al. surveyed 36 Korean architecture schools, 30 of which were accredited by the KAAB [55]. The schools' curricula were analyzed according to their respective architectural program reports, as well as online data from their websites, in order to determine the extent of sustainability education in their programs. The study identified a need for better integration of sustainability theory into studios and a general lack of sustainability awareness at all academic levels.

More widely, Álvarez et al. focused on education for sustainable architecture in Asian countries [19]. The authors compared the curricula of 20 selected schools across 11 counties, all with accredited undergraduate professional programs. Sustainability-related courses were identified, classified and compared between schools. The comparison comprised the extent to which sustainability-related content was offered, the general contents and organization of the courses throughout the programs and their integration with studios. It was concluded that the implementation of sustainability issues in the programs was inconsistent. Many of the programs dealt with environmental issues, with a focus on energy, while only a few programs included sociocultural issues. Almost all programs were deficient in addressing economic issues.

Most of the aforementioned researchers analyzed programs approved by their national accrediting boards. However, they did not address whether or not these accreditation systems supported, or hindered, the implementation of consistent sustainability education. As discussed in the 'Sustainable Architecture Education White Paper', sustainable architectural education needs full support from accreditation systems and regulatory bodies [13]. Therefore, it is unrealistic to expect real sustainable architectural education without an adequate framework for regulation that defines minimum standards.

The KAAB enters its 10th year of accreditation work, having granted accreditation to 56 programs. Therefore, the moment is right to analyze the aspects of its accrediting system that can be improved, in order to facilitate better integration of sustainability education in the programs. Furthermore, specific research on the course structures and sequences of Korean programs could not be found in the literature. For example, this included how and when sustainability issues are addressed in theory courses and studios. However, the examples addressed by studies discussed in this section are also important references for developing integrated sustainability education in Korean programs. Therefore, this research addresses the following questions:

- How has the sustainability education of programs been shaped within the framework of the KAAB accrediting system?

- Which aspects of the KAAB accrediting system support or hinder the development of sustainability education in programs? 
- To what extent are specific sustainability principles implemented in programs and in what order?

- Which sustainability-related contents are taught in theory courses and studios, and how are these two related to each other?

- Which program types can be identified, and how can program types be related to well-integrated sustainability education in programs?

\section{Materials and Method}

This research consists mainly of a quantitative and, to minor extent, a qualitative analysis of the KAAB's SPCs, with respect to sustainability principles and their integration into the curricula of accredited programs in Korea. This study aims to improve the integration of sustainability principles into architectural education systems, particularly in Asia. Specifically, the requirements for accreditation by the $\mathrm{KAAB}$, as well as the structure and content of programs at 48 accredited universities have been analyzed and evaluated. Based on the results of this research, we have made suggestions to improve both the KAAB accreditation system and the curricula of accredited university programs, in order to comprehensively integrate sustainability principles into the education of architects.

Previous research addressed the qualitative analysis of a few selected accredited Korean programs within the wider context of Asia [19]. This paper focuses exclusively on all accredited Korean programs. Therefore, a detailed and in-depth qualitative analysis is out of the scope of this paper. The primary quantitative approach of this research identifies trends and patterns of all of the programs regarding the implementation of sustainability content in their respective curricula. The present research will allow the selection of a more reduced number of significant cases that will be the starting point for more detailed research, including also qualitative analysis, in a future study.

Courses that addressed sustainability issues have been identified and analyzed by reviewing the architectural program report of each program. According to the KAAB's accreditation requirements, the architectural program reports need to refer to SPCs defined by the KAAB and be addressed to a sufficient degree in accredited university programs. The SPCs define specific topics that are divided into two categories: practical skills, with ability as a learning objective, and theoretical knowledge, with understanding as a learning objective. The specific skill or knowledge is directly associated with the comprehensive work of professional architects.

The proportions of knowledge-oriented theory courses and practice-oriented studios that address sustainability-related SPCs (hereafter, sustainability SPC) have been calculated for each of the 48 Korean programs included in this research. Furthermore, we analyzed the extent and the semester during which sustainability SPCs are taught, in both theory courses and studios. This enabled the identification of the extent to which specific sustainability principles were addressed, in the same semester, by both theory and studio courses. Reciprocally, we also identified if any specific SPC was addressed separately and not integrated into the curriculum of either course type.

The time assigned to an individual SPC in a course was calculated by dividing the study time, in hours, related to the course's credit points, by the total number of all SPCs addressed in that course. Both the study time devoted to specific sustainability-related SPCs and the parallel integration of such SPCs in both theory and studio courses were indicators of the degree of sustainability integration and comprehensiveness in the programs. Section 4 illustrates the characteristics, advantages and disadvantages in integrating sustainability principles in the 48 university programs. Section 5 discusses the research results. Section 6 summarizes the results and relates them to issues that need to be addressed in order to improve the KAAB accreditation system, with respect to comprehensively integrating sustainability principles into the architectural education in Korea, and elsewhere.

\subsection{Accreditation and Sustainability SPCS}

The Korea Architectural Accrediting Board (KAAB) was established in 2004. Initial program review started in November of 2006 with three programs. In total, 48 programs have been accredited as of February, 2016. To be accredited, an educational organization must submit an architectural 
program report with detailed descriptions of the program and curricula. The SPC matrix lists all courses within a curriculum and all SPCs addressed in a specific course. The SPC Matrix is necessary in the architectural program report, in order to verify that every SPC is reflected in the curriculum, based on individual program guidelines for each course.

The X-axis of the matrix consists of SPC numbers, while the Y-axis contains course titles, specifying whether a given course is a theory course or a studio. The courses are generally listed by semester, and each course is marked with the different SPCs addressed within it. The SPC matrix provides comprehensive information regarding the structure and content of a program. In total, the KAAB has defined 30 SPCs that are assigned to the categories of communication, cultural context, design, engineering/technology and professional practice. SPCs are assigned to the following two educational objectives: understanding, addressed mainly in theory courses; and ability, addressed primarily in studios [7]. Figure 2 shows an exemplary SPC matrix.

2015' SeoulTech SPC Matrix : 130 SPC [OUnderstanding, OAbility]

\begin{tabular}{|c|c|c|c|c|c|c|c|c|c|c|c|c|c|c|c|c|c|c|c|c|c|c|c|c|c|c|c|c|c|c|c|}
\hline \multirow[t]{2}{*}{ Year } & \multirow{2}{*}{$\begin{array}{c}\text { Coursc } \\
\text { SPC number }\end{array}$} & \multicolumn{2}{|c|}{\begin{tabular}{|l|} 
Commu \\
nication
\end{tabular}} & \multicolumn{6}{|c|}{ Cultural Context } & \multicolumn{10}{|c|}{ Design } & \multicolumn{8}{|c|}{ Enginecring/Technology } & \multicolumn{4}{|c|}{$\begin{array}{l}\text { Professional } \\
\text { Practice }\end{array}$} \\
\hline & & 1 & 2 & 3 & 4 & 3 & 6 & 1 & 8 & y & 10 & 11 & 12 & 13 & 14 & 15 & 16 & 11 & 18 & 19 & 20 & 21 & 22 & 23 & 24 & 25 & 26 & 21 & 28 & $2 y$ & 30 \\
\hline \multirow{2}{*}{$1-1$} & Introduction to Architecture & 1 & 2 & 0 & 4 & 5 & 6 & 0 & 8 & 9 & 10 & 11 & 12 & 13 & 14 & 15 & 16 & 17 & 18 & 19 & 20 & 21 & 22 & 23 & 24 & 25 & - & - & - & 29 & 30 \\
\hline & $\begin{array}{l}\begin{array}{l}\text { Architectural presentation \& } \\
\text { dwgs. }\end{array} \\
\end{array}$ & - & - & 3 & 4 & 5 & 0 & 7 & 8 & - & 10 & 11 & 12 & 13 & 14 & 15 & 10 & $\mid 17$ & 18 & 19 & 20 & 21 & 22 & 23 & 24 & 25 & 20 & 27 & 28 & 29 & 30 \\
\hline \multirow{3}{*}{$1-2$} & Basic Design Studio & 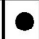 & $\bullet$ & 3 & 4 & 5 & 6 & 0 & 8 & ? & 10 & 11 & 12 & 13 & 14 & 15 & 16 & 17 & 18 & 19 & 20 & 21 & 22 & 23 & 24 & 25 & 26 & 27 & 28 & 29 & 30 \\
\hline & Understanding of Structure & 1 & 2 & 3 & 4 & 5 & 6 & 7 & 8 & 9 & 10 & 11 & 12 & 13 & 14 & 15 & 16 & 17 & 18 & 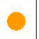 & - & 21 & 22 & 23 & 24 & b & 26 & 27 & 28 & 29 & 30 \\
\hline & Architectural Comouting1 & 1 & - & 3 & 4 & 5 & 6 & 7 & 8 & 9 & 10 & 11 & 12 & 13 & 14 & 15 & 16 & 17 & 18 & 19 & 20 & 21 & 22 & 23 & - & 25 & 26 & 27 & 28 & 29 & 30 \\
\hline \multirow{3}{*}{$2-1$} & Archi. Design Studio I & C & - & 3 & 4 & 5 & 6 & 7 & 8 & - & - & 11 & - & 13 & 14 & 15 & 16 & 17 & 18 & 19 & 20 & 21 & 22 & 23 & 24 & 25 & 26 & 27 & 28 & 29 & 30 \\
\hline & Building Structure & 1 & 2 & 3 & 4 & 5 & 6 & 7 & 8 & 9 & 10 & 11 & 12 & 13 & 14 & 15 & 16 & 17 & 18 & 0 & 0 & 21 & 22 & 23 & 24 & 25 & 26 & 27 & 28 & 29 & 30 \\
\hline & History of Arc & 1 & - & O & 0 & 5 & 0 & 1 & 8 & y & 10 & 11 & 12 & 13 & 14 & 15 & 16 & 11 & 18 & 19 & 20 & 21 & 22 & 23 & 24 & 25 & 26 & 21 & 28 & $2 y$ & 30 \\
\hline \multirow{4}{*}{$2-2$} & Archi. Design Studio 2 & 1 & $\bullet$ & 3 & 4 & 5 & 6 & 7 & 8 & 9 & 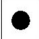 & - & 0 & - & 14 & 15 & 16 & 17 & 18 & 0 & 20 & 21 & 22 & 23 & 24 & 25 & 26 & 27 & 28 & 29 & 30 \\
\hline & Architectural Computing 2 & 1 & - & 3 & 4 & 5 & 6 & 7 & 8 & 9 & 10 & 11 & 12 & 13 & 14 & 15 & 16 & 17 & 18 & 19 & 20 & 21 & 22 & 23 & - & 25 & 26 & 27 & 28 & 29 & 30 \\
\hline & $\begin{array}{l}\text { Theory of Traditional Korean } \\
\text { Architecture }\end{array}$ & 1 & 2 & 0 & 4 & - & 6 & 7 & 8 & 9 & 10 & 11 & 12 & 13 & 14 & 15 & 16 & 17 & 18 & 19 & 20 & 21 & 22 & 23 & 24 & 25 & 20 & 27 & 28 & 29 & 30 \\
\hline & $\begin{array}{|ll|}\text { Archi. } & \text { Environmental } \\
\text { Planning } & \end{array}$ & 1 & 2 & 3 & 4 & 5 & 6 & 7 & 0 & 9 & 10 & 11 & 12 & 13 & 14 & 15 & 16 & 17 & 18 & 19 & 20 & - & - & 23 & 24 & 25 & 26 & 27 & 28 & 29 & 30 \\
\hline \multirow{4}{*}{$3-1$} & Archi. Design Studio 3 & 1 & - & 3 & 4 & 5 & 6 & 1 & 8 & 0 & 10 & 0 & 12 & 0 & 14 & 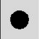 & 16 & 17 & 18 & 19 & 20 & 21 & 22 & 23 & O & ○ & 26 & 27 & 28 & 29 & 30 \\
\hline & Modern Architecture & 1 & 2 & O & 0 & 5 & 0 & 7 & 8 & 9 & 10 & 11 & 12 & 13 & 14 & 15 & 16 & 17 & 18 & 19 & 20 & 21 & 22 & 23 & 24 & 25 & 26 & 27 & 28 & 29 & 30 \\
\hline & \begin{tabular}{|l|l|}
$\begin{array}{l}\text { Architectural Materials \& } \\
\text { Methods }\end{array}$ \\
\end{tabular} & 1 & 2 & 3 & 4 & 5 & 0 & 7 & 8 & 9 & 10 & 11 & 12 & 13 & 14 & 15 & 0 & 17 & 18 & ○ & ○ & 21 & 22 & 23 & 24 & 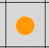 & 20 & 27 & 28 & 29 & 0 \\
\hline & Construction Technology & 1 & 2 & 3 & 4 & 5 & 6 & 7 & 8 & 9 & 10 & 11 & 12 & 13 & 14 & 15 & 16 & 17 & 18 & 19 & 0 & 21 & 22 & 23 & 24 & 0 & 0 & 27 & 28 & 29 & 30 \\
\hline
\end{tabular}

Figure 2. Example of a Student Performance Criteria (SPC) matrix showing which course addressed specific SPC numbers and in which year and semester the course was taught. The SPC matrix also shows which SPC numbers addressed communication, cultural context, design, engineering/technology and professional practice; and if they were assigned to the learning goals of understanding or ability.

Here, all 30 SPCs have been analyzed to find out if they address at least one of the following three sustainability categories: environmental, economic and sociocultural quality. In order to be selected, the SPC must address sustainability issues in the title and/or in the explanatory text outlining its specific content. As a result, eight sustainability-related SPCs could be identified (SPC Numbers 8, $12,15,16,21,22,23$ and 25). Five SPCs $(8,21,22,23,25)$ were only assigned to the learning goal understanding; two $(12,16)$ were only assigned to the learning goal ability; and one (15) was assigned to both understanding and ability (Table 1). 
Table 1. Sustainability-related KAAB SPCs with SPC number, title, and explanation of the SPC content, as well as classification of the education objectives $U$ (understanding) and A (ability).

\begin{tabular}{|c|c|c|c|c|}
\hline \multirow{2}{*}{ SPC Number } & \multirow{2}{*}{ SPC Title } & \multirow{2}{*}{ SPC Content Explanation } & \multicolumn{2}{|c|}{ Classification } \\
\hline & & & $\mathbf{U}$ & A \\
\hline 8 & $\begin{array}{l}\text { Sustainable City } \\
\text { and Architecture }\end{array}$ & Understand urban and architectural sustainability. & $\bullet$ & \\
\hline 12 & Site Preparation & $\begin{array}{l}\text { Ability to formulate a design concept based on an } \\
\text { understanding of the cultural and historical } \\
\text { context of a site; systematically analyze and assess } \\
\text { data and information; and utilize the findings in } \\
\text { the design resolution. }\end{array}$ & & $\bullet$ \\
\hline 15 & $\begin{array}{l}\text { Integration of Building } \\
\text { Systems in Design }\end{array}$ & $\begin{array}{l}\text { Understand a building system and its constituent } \\
\text { elements such as building structure, envelope, } \\
\text { mechanical and electrical components and other } \\
\text { building components, and ability to integrate } \\
\text { these concepts into a design. }\end{array}$ & $\bullet$ & $\bullet$ \\
\hline 16 & $\begin{array}{l}\text { Design of } \\
\text { Addition/Alteration, } \\
\text { Repair and Maintenance }\end{array}$ & $\begin{array}{l}\text { Ability to assess and make changes, or maintain } \\
\text { the form or functions of existing buildings, in } \\
\text { order to renovate, rebuild, remodel and/or } \\
\text { repair them. }\end{array}$ & & $\bullet$ \\
\hline 21 & $\begin{array}{l}\text { Sustainable Means of } \\
\text { Environment Control }\end{array}$ & $\begin{array}{l}\text { Understand sustainable environmental control } \\
\text { and cyclic natural processes. }\end{array}$ & $\bullet$ & \\
\hline 22 & $\begin{array}{l}\text { Environment Control } \\
\text { Systems }\end{array}$ & $\begin{array}{l}\text { Understand the basic principles of the } \\
\text { environmental system, and assess thermal, light, } \\
\text { sound, environment, and energy management. }\end{array}$ & $\bullet$ & \\
\hline 23 & Building Service Systems & $\begin{array}{l}\text { Understand the basic principles and selection of } \\
\text { appropriate building service systems, such as } \\
\text { mechanical, electrical, communication, and } \\
\text { disaster protection systems. }\end{array}$ & $\bullet$ & \\
\hline 25 & $\begin{array}{l}\text { Building Materials } \\
\text { and Recycling }\end{array}$ & $\begin{array}{l}\text { Understand the manufacturing process and } \\
\text { application of building materials based on basic } \\
\text { knowledge of material characteristics, building } \\
\text { components, traditional usage, material } \\
\text { standards, recyclability, maleficence, and other } \\
\text { material control measures. }\end{array}$ & $\bullet$ & \\
\hline
\end{tabular}

\subsection{Sustainability Related Courses and Sustainability Core Courses}

All compulsory courses (studios and theory courses, excluding elective courses) for each of the $48 \mathrm{KAAB}$-accredited five-year programs have been analyzed. Students are required to take an average of 28.02 mandatory courses ( 2.8 per semester), counting for 105.15 credits (10.5 per semester) that accumulate $64.12 \%$ of the 164 credits necessary for graduation. These 164 credits (16.4 credits per semester) include major electives, general non-major electives and non-elective courses (Table 2).

Table 2. Average number of credits and courses required for graduation from the $48 \mathrm{KAAB}$-accredited five-year programs.

\begin{tabular}{ccc}
\hline $\begin{array}{c}\text { Required Credits for Graduation } \\
(\% \text { of Total) }\end{array}$ & $\begin{array}{c}\text { Credits for Compulsory Courses } \\
\text { (\% of Total) }\end{array}$ & Number of Compulsory Courses \\
\hline $164(100 \%)$ & $105.16(64.12 \%)$ & 28.02 \\
\hline
\end{tabular}

Compulsory theory courses that contained at least one of the eight sustainability-related SPCs were assigned to the course category "sustainability-related courses". Sustainability-related courses that extensively dealt with one of the five categories: Environment (E), Integration (I), Material (MA), Mechanical, Electrical and plumbing (ME) and Site (SI) were assigned to the course category "sustainability core course". All remaining courses that did not qualify as "sustainability core course" were assigned to the category of "sustainability partly related course" (Table 3 and Figure 3). 
Table 3. Sustainability core course categories and exemplary course names.

\begin{tabular}{cll}
\hline $\begin{array}{c}\text { Category } \\
\text { Abbreviations }\end{array}$ & $\begin{array}{l}\text { Sustainability Core } \\
\text { Course Category }\end{array}$ & Exemplary Courses Names \\
\hline E & Environmental courses & $\begin{array}{l}\text { Principles of Architectural Environments, } \\
\text { Architectural Environment Planning, } \\
\text { Architectural Environmental Control Systems }\end{array}$ \\
\hline I & Integrated courses & $\begin{array}{l}\text { Building Systems, Facade Systems, } \\
\text { Architectural Details }\end{array}$ \\
\hline MA & Material courses & Architectural Materials and Methods \\
\hline ME & Mechanical, Electrical and & Architectural HVAC \\
\hline plumbing courses & Site-related courses & $\begin{array}{l}\text { Site Design, Landscape Architecture } \\
\text { Urban Planning and Design, Understanding Cities }\end{array}$ \\
\hline
\end{tabular}

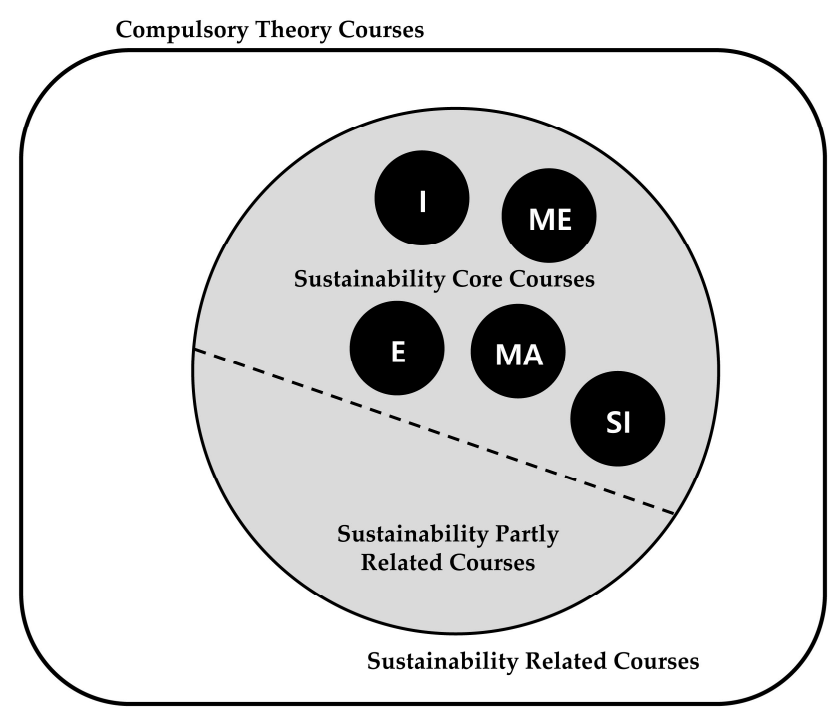

Figure 3. Illustration of sustainability-related courses within the total number of compulsory theory courses. Sustainability-related courses are differentiated into sustainability core courses and sustainability partly related courses.

The average number of credits assigned to different SPCs addressed in a specific course needed to be quantified, in order to analyze the quantitative integration of sustainability SPCs into sustainability partly-related courses, sustainability core courses, and studios. To calculate the average number of credits assigned to each SPC, the full number of credits assigned to one course was divided by the total number of SPCs assigned to the same course, using the following formula: total number of sustainability SPC credits = (total number of course credits $\mathrm{x}$ number of sustainability SPCs in the course)/total number of SPCs in the course.

For example, one studio had a total of six credits and addressed five sustainable SPCs out of a total of eight assigned SPCs. Thus, the total number of sustainability SPCs for this studio was $(6 \times 5) / 8=3.75$. In other words, 3.75 credits out of the six credits were designated to sustainability. Section 4 assesses the curricular structure of the courses analyzed, focusing on the sustainability SPCs, the distribution of sustainability SPCs in the curricula and the sequential framework of studios and sustainability core courses. 


\section{Analysis}

\subsection{Structure of Curricula Focusing on Sustainability SPCS}

Section 4.1.1 discusses the distribution of average total credits assigned to the five sustainability core course categories, in relation to all sustainability-related courses $(100 \%)$, while Section 4.1.2 analyzes the average distribution ratio of specific sustainability SPCs in studios and sustainability core courses.

\subsubsection{Total Sustainability Core Course Credit Distribution Ratios}

The focus of the remaining sections is on the eight sustainability SPCs. Here, the total amount of credits assigned to each of the five sustainability core course categories is evaluated to illustrate the average total credit ratio of the five course categories, in order to identify foci on specific topics and categories. The sustainability core courses at all 48 programs account for an average of $65.9 \%$ of all credits assigned to sustainability-related courses. The relative distribution of credits amongst each of the five sustainability core course categories (Figure 4) illustrates that integration has the highest portion of credits $(25.7 \%)$, followed by environment $(22.4 \%)$, site $(18.7 \%)$, mechanical, electric and plumbing $(16.8 \%)$ and material $(16.4 \%)$.

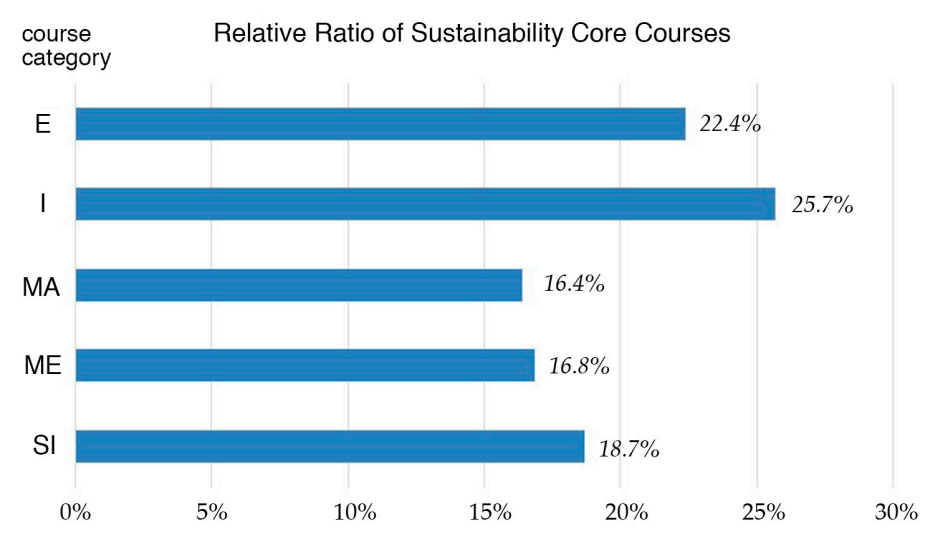

Figure 4. Relative distribution ratio of the total credits assigned to the five sustainability core course categories (E, I, MA, ME and SI). The total of $100 \%$ in this graph correlates with $65.9 \%$ of all SPC credits assigned to sustainability-related courses.

\subsubsection{Sustainability SPC Distribution Ratio in Studios and Sustainability Core Courses}

The average distribution ratio of specific sustainability SPCs in studios and sustainability core courses is analyzed by dividing the percent of total credits $(100 \%)$ by the number of credits from the eight sustainability SPCs assigned to each of the two course types. For example, if the number of SPC credits were distributed equally, the SPC percentage in both course types would be $100 \% / 8=12.5 \%$. However, in both course types, the accumulated credits are not assigned equally to the eight SPCs (Figure 5). In studios, SPC 12 ranked the highest (32.9\%), followed by SPC $15(24.3 \%)$, SPC $16(17.6 \%)$, SPC $8(8.2 \%)$, SPC $21(5.3 \%)$, SPC $25(5.1 \%)$, SPC $23(3.9 \%)$ and SPC $22(2.7 \%)$. The distribution ratio in sustainability core courses shows the opposite trend. Here, SPC 22 scores highest $(20.1 \%)$, followed by SPC $8(18.1 \%)$, SPC 21 (17.7\%), SPC $23(16.3 \%)$, SPC $25(14 \%)$, SPC $15(7.4 \%)$, SPC $12(4.1 \%)$ and SPC $16(2.2 \%)$.

The reason for this polarized distribution can be found in the assigned learning objectives for each SPC. SPCs 12, 15 and 16, which are prevalent in studios, focus on ability; whereas, the other SPCs focus on understanding. Only SPC 15 addresses both learning objectives; however, the distribution ratio illustrates that the main foci of this SPC are on ability and integration in the studio. For example, SPC 12, site preparation, is popular among studios, regardless of the curriculum year or semester, 
because most studios usually assign actual sites for the students' design projects. As such, the site is the first object to analyze at the beginning phase of the design process. SPCs $21,22,23$ and 25 pertain to technology and are labeled as understanding SPCs; therefore, they are more prevalent in sustainability core courses (Figure 5).

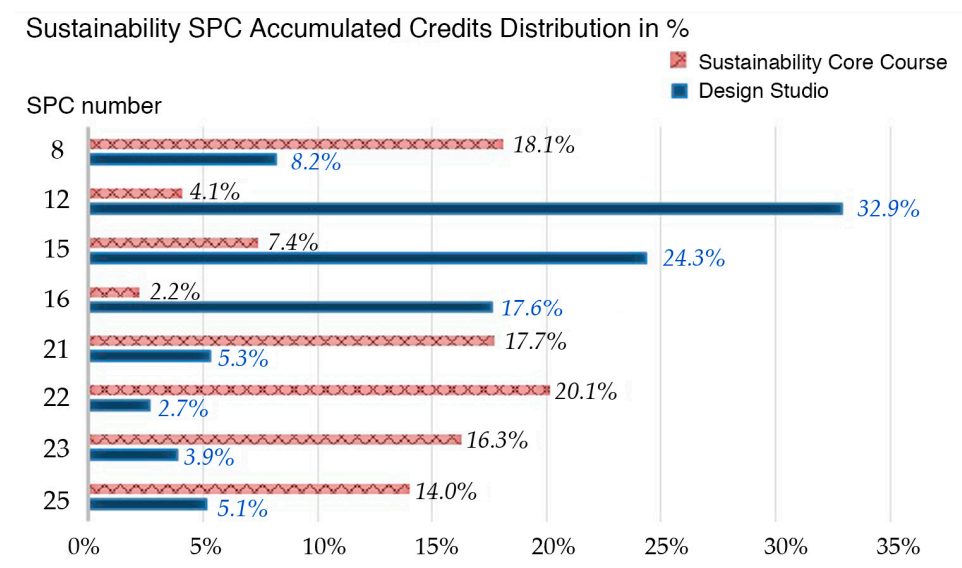

Figure 5. Distribution ratio of accumulated sustainability SPC credits assigned to specific SPCs in studios and sustainability core courses. The percentages refer to $100 \%$ of the accumulated sustainability SPC credits assigned to each of the two course types.

\subsection{Distribution of Sustainability SPCs in the Curricula}

The accumulated credits for the eight sustainability SPCs of studios and sustainability core courses in 48 accredited universities in Korea have been collected for quantitative analysis (Table 4). The data have been illustrated in a scatter chart for interpreting co-relationship between studios and sustainability core courses (Figure 6). The average accumulated sustainability SPC credits are 10.15 for studios and 10.23 for sustainability core courses. For studios, the median value is 9.42 , and the first- and third-quartile ranges are between 8.38 and 11.30. For sustainability core courses, the median value is 10.50, and the first- and third-quartile ranges are between 8.53 and 12.55. In general, more sustainability SPC credits are assigned to sustainability core courses than studios. Moreover, the credit distribution for sustainability core courses is wider than for studios.

Table 4. Accumulated credits for the 8 sustainability SPCs of studios and sustainability core courses in 48 accredited Korean programs. Please refer to Table A1 for the universities that are assigned to specific program numbers.

\begin{tabular}{|c|c|c|c|c|c|}
\hline \multirow{2}{*}{$\begin{array}{l}\text { Program } \\
\text { Number }\end{array}$} & \multicolumn{2}{|c|}{ Accumulated Sustainability SPC Credits } & \multirow{2}{*}{$\begin{array}{l}\text { Program } \\
\text { Number }\end{array}$} & \multicolumn{2}{|c|}{ Accumulated Sustainability SPC Credits } \\
\hline & Studios & Sustainability Core Course & & Studios & Sustainability Core Course \\
\hline 1 & 8.36 & 13.25 & 25 & 8.80 & 10.79 \\
\hline 2 & 5.88 & 11.00 & 26 & 8.77 & 7.80 \\
\hline 3 & 9.90 & 7.50 & 27 & 6.30 & 7.50 \\
\hline 4 & 11.25 & 4.58 & 28 & 6.25 & 9.75 \\
\hline 5 & 9.28 & 14.00 & 29 & 14.50 & 4.50 \\
\hline 6 & 8.83 & 12.05 & 30 & 14.90 & 8.95 \\
\hline 7 & 8.95 & 9.75 & 31 & 10.10 & 6.30 \\
\hline 8 & 9.50 & 10.75 & 32 & 12.50 & 14.80 \\
\hline 9 & 8.89 & 10.75 & 33 & 8.00 & 13.25 \\
\hline 10 & 8.33 & 15.00 & 34 & 7.79 & 11.50 \\
\hline 11 & 16.50 & 10.50 & 35 & 13.40 & 7.50 \\
\hline 12 & 10.70 & 14.17 & 36 & 6.92 & 10.25 \\
\hline 13 & 25.33 & 6.00 & 37 & 11.86 & 10.85 \\
\hline 14 & 13.20 & 12.56 & 38 & 10.16 & 13.50 \\
\hline
\end{tabular}


Table 4. Cont.

\begin{tabular}{|c|c|c|c|c|c|}
\hline \multirow{2}{*}{$\begin{array}{l}\text { Program } \\
\text { Number }\end{array}$} & \multicolumn{2}{|c|}{ Accumulated Sustainability SPC Credits } & \multirow{2}{*}{$\begin{array}{l}\text { Program } \\
\text { Number }\end{array}$} & \multicolumn{2}{|c|}{ Accumulated Sustainability SPC Credits } \\
\hline & Studios & Sustainability Core Course & & Studios & Sustainability Core Course \\
\hline 15 & 10.75 & 10.00 & 39 & 13.17 & 10.50 \\
\hline 16 & 8.59 & 12.40 & 40 & 9.80 & 16.75 \\
\hline 17 & 3.30 & 8.55 & 41 & 8.40 & 9.75 \\
\hline 18 & 10.00 & 10.25 & 42 & 11.17 & 10.25 \\
\hline 19 & 10.84 & 7.95 & 43 & 19.50 & 11.25 \\
\hline 20 & 9.12 & 9.75 & 44 & 9.00 & 15.00 \\
\hline 21 & 4.41 & 13.50 & 45 & 11.59 & 12.54 \\
\hline 22 & 9.34 & 15.00 & 46 & 10.30 & 7.50 \\
\hline 23 & 8.49 & 12.00 & 47 & 6.00 & 9.50 \\
\hline 24 & 11.36 & 8.50 & 48 & 6.70 & 8.20 \\
\hline
\end{tabular}

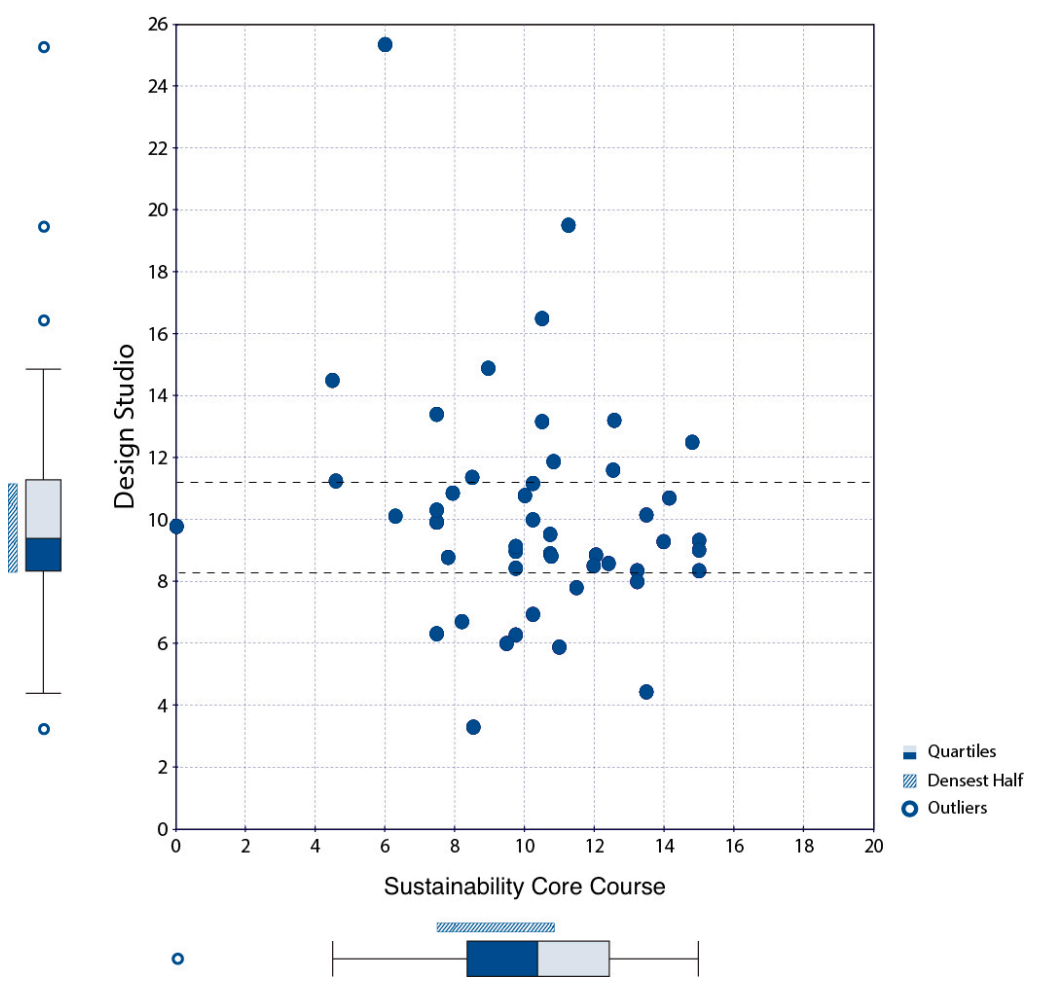

Figure 6. Distribution of the accumulated sustainability SPC credits from sustainability core courses and studios at the 48 accredited programs in South Korea. Accumulated sustainability SPC credits for studios are assigned to the Y-axis. Accumulated sustainability SPC credits for sustainability core courses are assigned to the $\mathrm{X}$-axis. Median values and first- and third-quartile ranges for both the $\mathrm{X}$-and Y-axes show the distribution characteristics of accumulated sustainability SPC for both course types.

The interrelationship between sustainability education in studios and sustainability core courses is investigated by analyzing and comparing the average amount of accumulated credits assigned to each of the eight sustainability SPCs and their distribution among the five study years (Figure 7).

The results illustrate that three of the eight sustainability SPCs are primarily assigned to studios. These include site preparation (SPC 12); integration of building systems in design (SPC 15); and design of addition/alteration, repair and maintenance (SPC 16). SPC 12 is generally addressed in the second and third years of study, while SPC 16 is taught mainly in the third and fourth years. SPC 15 is taught in the third year, but generally addressed more in the fourth and fifth years (Figure 7).

Conversely, five out of eight SPCs are primarily addressed in sustainability core courses. These include sustainable cities and architecture (SPC 8); sustainable means of environmental control (21); environmental control systems (22); building service systems (23); and building materials and recycling 
(25). Most accumulated sustainability core course credits are assigned to SPC 25, followed by SPCs 22 , 21 and 23. The three dominant SPCs-25, 22 and 21—are mainly included in the curricula of the first three years, while SPC 23 is mainly addressed in the fourth and fifth years (Figure 7).

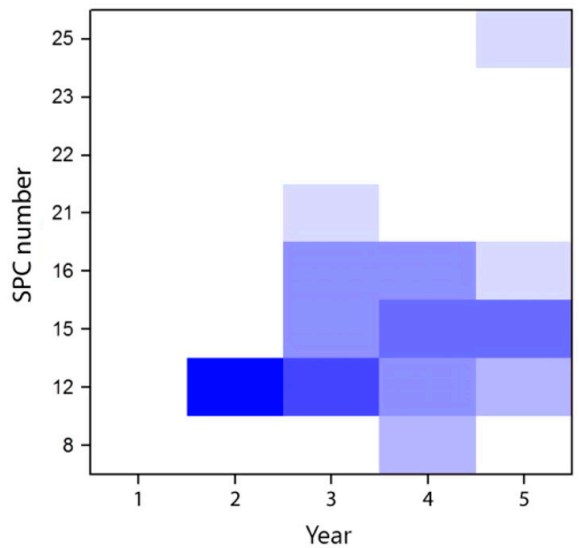

(a)
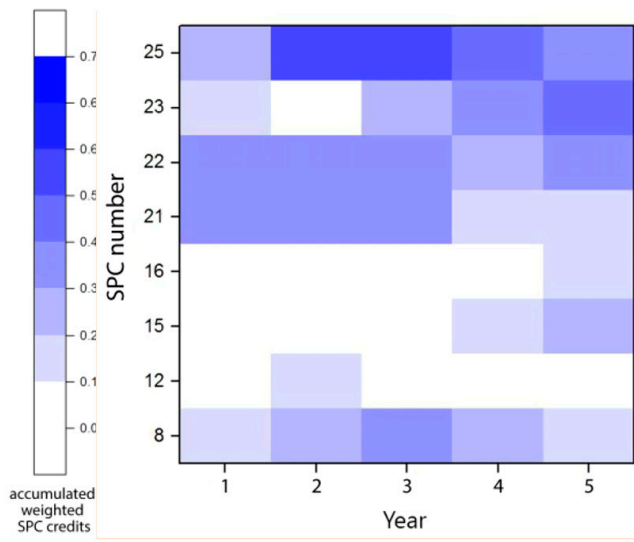

(b)

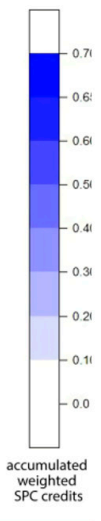

Figure 7. Distribution of the average accumulated credits for each of the eight sustainability SPCs (Y-axis) for (a) studios and (b) sustainability core courses, among the five study years (Y-axis) at 48 accredited programs in South Korea.

Comparison of the accumulated credits for sustainability SPCs in studios and sustainability core courses over five years of study at the 48 accredited programs in South Korea illustrates the unbalanced distribution of SPCs among the two course types, as well as the clear separation of theory and studio courses. As evidence, the three SPCs with the learning objective ability (SPCs 12,15, 16) are primarily addressed in studios, while the SPCs focusing on understanding, with the exception of SPC 15, are generally assigned to sustainability core courses. The segregation of SPCs to specific course types causes insufficient integration of theory and practice, both in terms of course curricula and the structure of the SPCs. Section 4.3 evaluates the integration of theory courses and practice-oriented studios.

\subsection{Sequence of Sustainability SPC Credit Distribution in Studios and Sustainability Core Courses}

The sequence and quantity of sustainability SPC credits in studios and sustainability core courses during each of the five study years indicates the extent of sustainable education in terms of the integration of knowledge (understanding) and design (ability). The relation between sustainable architectural education in studios, which focus on ability, and sustainability core courses, which focus on understanding, over each of the five study years is analyzed by comparing the total amount of sustainability SPCs addressed in each of the two kinds of courses.

The distribution density of accumulated credits for sustainability SPCs in studios is narrow compared to those in sustainability core courses (Figure 6). Therefore, only programs with accumulated studio credits within a range of 8.38-11.30 are selected for a comparative sequential analysis of sustainability SPC credit distribution. As a result, 25 out of the 48 accredited programs have been selected for further analysis. Please refer to Supplementary Materials for figures with the distribution of accumulated sustainability SPC in studios and sustainability core courses during a five-year period of all 48 programs.

In the following text, each program is identified by the case number assigned in Table 4. According to the research results, the following four sequence categories could be identified: sustainability core course preceding (hereafter, preceding type), sustainability core course and studio accompanying (hereafter, accompanying type), sustainability core course following (hereafter, following type), and fluctuation (hereafter, fluctuation type). In the following sections, the main results from 19 of the 23 programs are presented: eight programs are assigned to the sequence category preceding type 
curriculum; six to the accompanying type curriculum; two to the following type curriculum; and three to the fluctuation type curriculum. The remaining seven programs are not presented, because they could not be clearly assigned to any of the typologies.

\subsubsection{Preceding Type Curricula}

The number of accumulated sustainability SPC credits per study year in preceding type curricula could be identified in eight programs. Here, sustainable architectural education is conducted in the first three years of study, mainly through theory courses with SPCs focusing on understanding. In the fourth and fifth year of study, sustainable architectural education is executed in studios, with SPCs focusing on ability. Accordingly, programs with preceding type curricula believe that theoretical knowledge should be taught, well before it is applied in studios.

In five programs (Figure 8), most sustainability SPC credits are assigned to sustainability core courses from the second to fourth years, and the highest amount of accumulated credits is in the second or third year. Most accumulated sustainability SPC credits are assigned to studios from the second to fifth years, with the highest amount of accumulated credits in the fourth year (Figure 8 , Programs 9, 6, 1, and 3), except Program 7, where they accumulate in the third year (Figure 8, Program 7). In all five programs, credits assigned to studios gradually increase, with a maximum amount of accumulated credits in the third (Figure 8, Program 7) or fourth year (Figure 8, Programs 9, 6, 1 and 3).

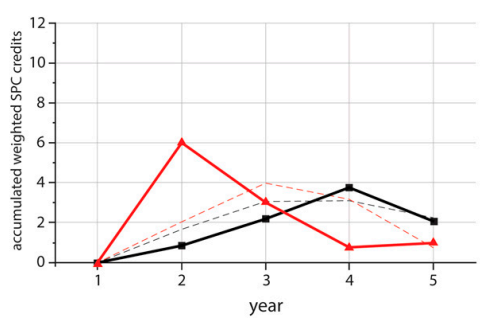

Program 9

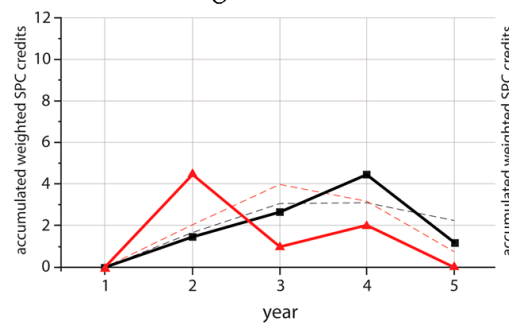

Program 3

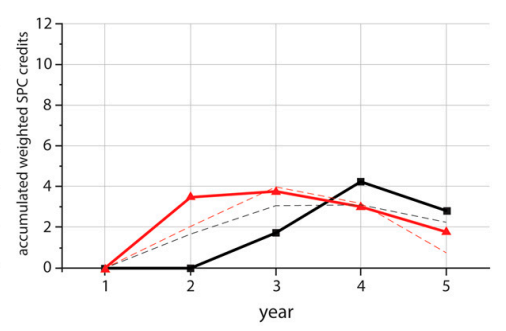

Program 6

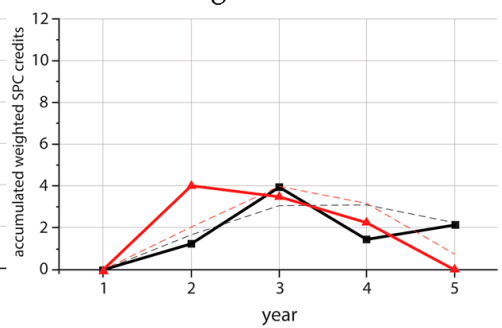

Program 7

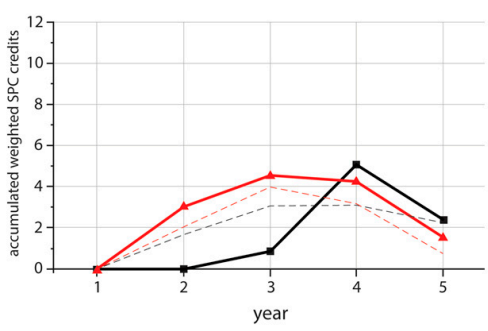

Program 1

Figure 8. Distribution of accumulated sustainability SPC credits (Y-axis) assigned per year (X-axis) to studios (black lines) and sustainability core courses (red lines), during the five-year education period in preceding type curricula. The graphs illustrate the sequence of SPC credit distribution for studios and sustainability core courses of preceding type Programs 9, 6, 1, 3 and 7.

Three programs assign sustainability SPC credits mainly in the second and third years. Preceding type Programs 8, 33 and 10 (Figure 9) follow a comparable pattern in studios and sustainability core courses. The gap between accumulated credits assigned to sustainability core courses and studios is significant, particularly in the second year, and illustrates that the focus of sustainable architectural education in these programs is more on understanding, than on ability and integrated design. As evidence, the accumulated credits assigned to sustainability SPCs declines significantly after the third year, which indicates a sustainable architectural education discontinuity in these programs.

Preceding type Programs 33 and 10 (Figure 9) have the largest gaps between accumulated sustainability credits assigned to sustainability core courses and studios during the first two years. In the case of preceding type Program 10, the studio and theory courses do not have sustainability 
SPC credits in the fourth year, but have a considerable amount in the fifth year. Such interruption can be an impediment to achieve a continuous integration of sustainability education into the curriculum.

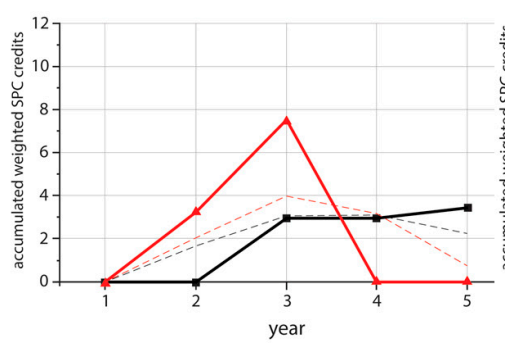

Program 8

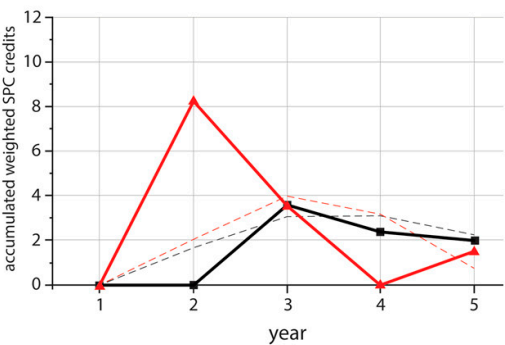

Program 33

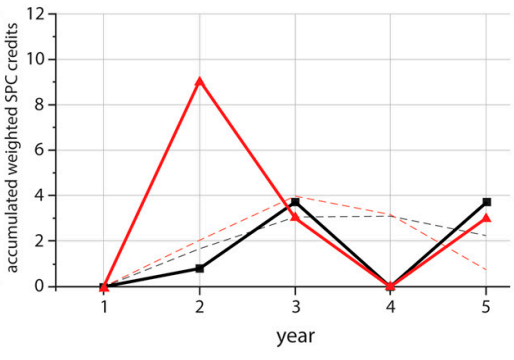

Program 10

Figure 9. Distribution of accumulated sustainability SPC credits (Y-axis) for preceding type curricula assigned per year (X-axis) to studios (black lines) and sustainability core courses (red lines) during a five-year period. There are significant gaps in sequence and accumulated sustainability SPCs in sustainability core courses and studios in the CP curricula for preceding type Programs 8, 33 and 10.

\subsubsection{Accompanying Type Curricula}

Six programs' curricula could be assigned to an accompanying or parallel type. These curricula address a comparable amount of sustainability SPC credits in sustainability core courses and studios. The number of sustainability SPC credits addressed in studios is highest during the third and fourth years (Figure 10). This distribution pattern is comparable with that of the preceding type curricula discussed in the previous section (Figures 8 and 9). A similar amount of credits assigned to course types focusing on ability and understanding suggests that the content taught in theory courses could be integrated with the practice-oriented studios in a balanced way. The distribution sequences of the six curricula (Figure 10) illustrate a generally continuous and gradually rising integration of accumulated sustainability SPC credits until the fourth year, with a significant decrease in credits during the last year of study.

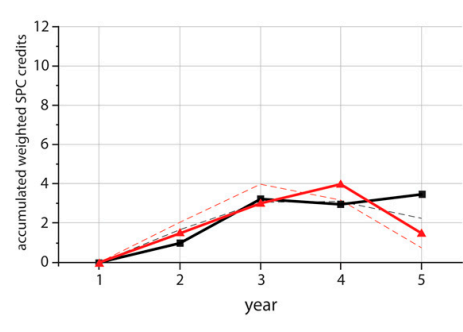

Program 15

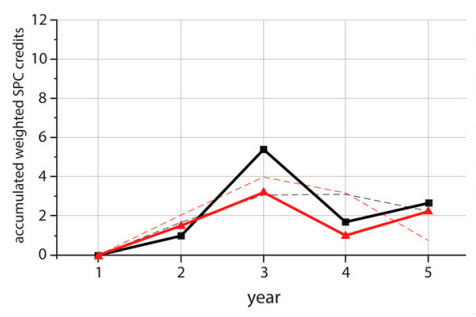

Program 19

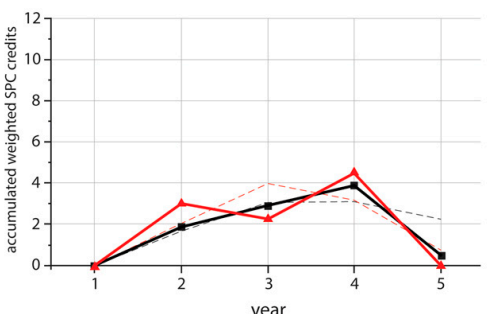

Program 20

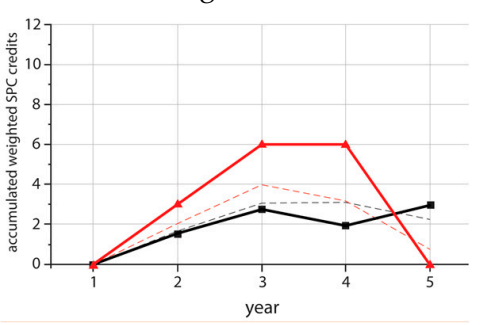

Program 22

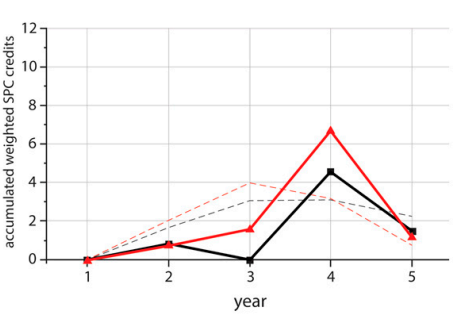

Program 36

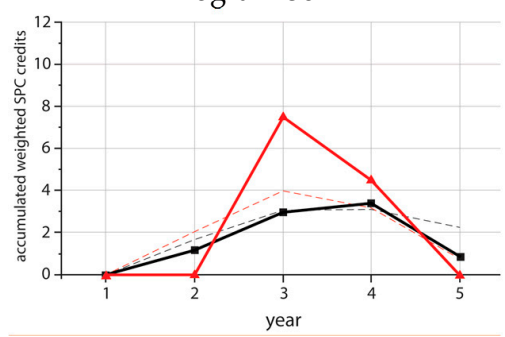

Program 23

Figure 10. Distribution of accumulated sustainability SPC credits (Y-axis) assigned per year (X-axis) to studios (black lines) and sustainability core courses (red lines) during a five-year education period for accompanying type curricula. Similar credit distribution patterns are apparent, with increasing credits from the first to fourth years of study for both course types at accompanying type Programs 15, 20, 36, 19,22 and 23. 
Due to this balanced distribution of sustainability SPC credits in sustainability core courses and studios, accompanying type curricula suggest the potential to generate a well-structured and well-suited integration of theory and practice. Here, the accumulated sustainability SPC credits are assigned continuously to studios, and are bolstered by a considerable amount of credits assigned to sustainability core courses.

\subsubsection{Following and Fluctuation Type Curricula}

Compared with the previously discussed preceding type curricula, the two following type Programs 5 and 16 (Figure 11) have opposite sequence and distribution patterns for sustainability SPC credits assigned to sustainability core courses and studios. A similar amount of sustainability SPC credits is assigned to both kinds of courses during the first three years of study, with increasing frequency (comparable with Program 15 in Figure 10); whereas, more credits are assigned to theory courses than to studios. Furthermore, a majority of sustainability SPC credits are assigned to theory courses in the fourth study year. In the fifth year, no sustainability SPC credits are assigned to sustainability core courses or studios (Figure 11). Accordingly, following type Programs 5 and 16 suggest less potential to integrate theoretical knowledge in studios, particularly during the last two years of study.

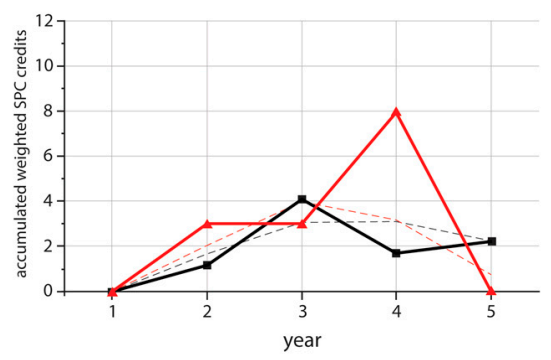

Program 5

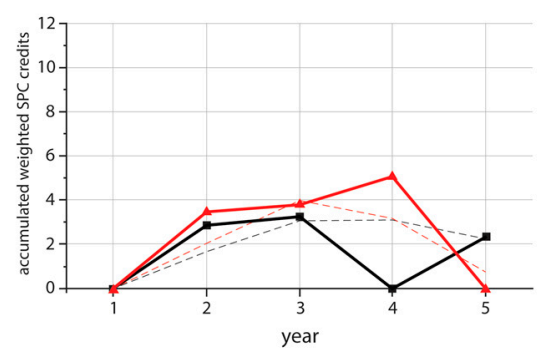

Program 16

Figure 11. Distribution of accumulated sustainability SPC credits (Y-axis) assigned per year (X-axis) to studios (black lines) and sustainability core courses (red lines) during the five-year education period of following type Programs 5 and 16. There is an apparent inconsistency in accumulated sustainability SPC credits assigned to studios compared with those assigned to sustainability core courses in the last two years of study.

Three curricula are categorized as fluctuation type curricula (Figure 12). Fluctuation type Programs 26, 41 and 42 follow a fluctuating and unbalanced distribution pattern of accumulated sustainability SPC credits per study year assigned to sustainability core courses and studios. Fluctuation type Program 26 only addresses sustainability SPC credits in sustainability core courses during the first and third study years. Fluctuation type Program 41 does not address sustainability SPC credits in sustainability core courses during the second year, and fluctuation type Program 42 does not address sustainability SPC credits in sustainability core courses during the first and third years. Due to fluctuating credit distribution patterns, no consistency regarding the integration of sustainability core courses into studios could be found. Furthermore, the sustainability education in theory courses is limited to certain years. Accordingly, the continuity of theoretical discourse is more challenged in the fluctuation type Programs 26, 41 and 42 (Figure 12). 


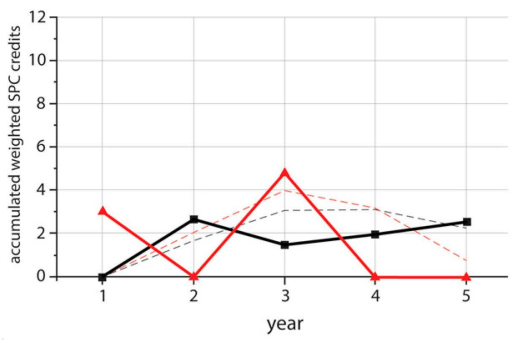

Program 26

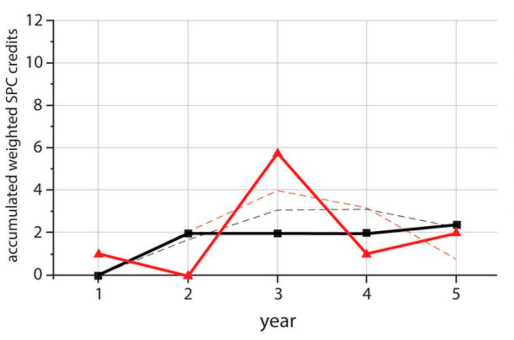

Program 41

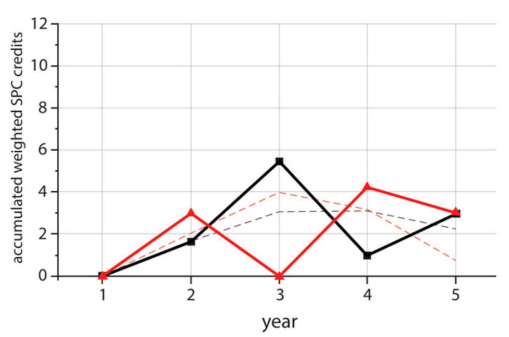

Program 42

Figure 12. Distribution of sustainability SPC credits (Y-axis) assigned per year (X-axis) to studios (black lines) and sustainability core courses (red lines) during a five-year education period of fluctuation type Programs 26, 41, and 42. The unbalanced distribution of credits assigned to studios and sustainability core courses is obvious in specific study years.

\section{Discussion}

This research on the integration of sustainability issues into the architectural education in South Korea is based on a general analysis of SPC distribution and weighting at 48 accredited programs. The applied methodology has limited scope, because details of the individual program syllabi and course plans are not analyzed. However, the research results discussed in the previous section reveal clear limitations in the current $\mathrm{KAAB}$ accreditation system.

Analysis of the 48 programs revealed a particular weakness in integration between sustainability core courses and studios in a majority of curricula. The literature review confirms that sufficient integration of theory courses with studios is essential to create a successful sustainable program. In turn, this integration can better motivate students to apply theoretical knowledge in their architectural design work, develop their critical thinking and strengthen their knowledge and abilities [49]. The aforementioned integration issues are discussed in more detail in the following sections.

\subsection{Separation between Studios and Sustainability Core Courses in Terms of Information Delivery}

According to the KAAB, SPCs are assigned to two main learning objectives, understanding and ability, which are related to specific educational methodologies. With the exception of SPC 15 (integration of building systems in design), the eight sustainability SPCs selected for this research are also related to these two learning objectives. The KAAB guidelines for accreditation specify that SPCs addressing understanding are generally covered by theory lecture courses, and SPCs addressing ability are covered by studio courses [7].

This distinction between course types and learning objectives can be a barrier to integrating theoretical knowledge and practical skills, because programs are designed according to KAAB regulations in order to achieve accreditation. Accordingly, programs generally do not address SPCs assigned to understanding in studios, because according to the KAAB, such SPCs should be applied to theory courses. This research finds that all programs follow this KAAB guideline, regardless of the sequence and distribution of sustainability SPC credits in sustainability core courses and studios during a five-year study period.

The general learning goal of sustainable architectural education is to develop the students' ability to design and plan integrated architecture projects that meet sustainability criteria, rather than accumulate purely theoretical knowledge. Thus, a close integration and application of theory and practice can make a positive impact. One reason for this poor integration of theory courses with studios may be the KAAB accreditation system itself. The main identified barriers are a clear separation of SPCs in understanding and ability-based learning goals, segregated assignments of these goals to sustainability core courses and studios, and the way in which the KAAB accreditation system enforces this separation. 
This study suggests that the KAAB accreditation system be revised, in order to facilitate a closer and more rigorous integration of theoretical knowledge into design studio work. A revised accreditation process should verify that theoretical knowledge of sustainability issues is well understood by students in theory courses (or course modules), and that students are able to apply this knowledge in the design of sustainable architecture. Furthermore, a basic knowledge of sustainable architecture requires relevant design skills to be developed in studios. Thus, the KAAB accreditation system should reflect more flexible and qualitative criteria based on SPC categorization and verification, in order to improve the quality of sustainable architectural education, and achieve a better integration of theory and practice.

\subsection{Unbalanced Distribution of Sustainability SPCs in Program Curricula}

Another issue identified in the present research is the unbalanced distribution of sustainability SPCs in program curricula. In experiencing architectural education in South Korean Universities, the authors have realized that studios are addressing a growing number of SPCs in later years of study. In turn, students' skills advance during their studies, because they accumulate more theoretical knowledge, and are able to develop more practical skills to apply this knowledge. This is also true for sustainability issues, as diverse aspects of sustainability need to be gradually introduced by increasing the number of projects relating to sustainable principles and issues, as well as the complexity of the design problem.

However, this tendency requires designating sustainability-related SPCs in studios during later years of study. If sustainability issues are not integrated with both theory courses and design studios early in architectural education, it is difficult to successfully teach an integrated sustainable architecture curriculum. For example, a student who is trained in site analysis and design early on in his or her education, without previous knowledge of passive design strategies, cannot become familiar with addressing climatic and microclimatic issues during the design process. Such a deficiency is likely to remain during later years of study.

Similarly, upper-level students who are introduced to building service systems and engineering technologies often disregard sustainability issues related to the basic conditions of the site. Therefore, theoretical knowledge and practical skills addressed through coursework need to build on skills and knowledge gained in previous courses. Similar issues are found in architectural material selection. Students learn about the properties of architectural materials during the early part of their education. However, they do not learn how to utilize and integrate this knowledge in the material selection process for studios during their later years of study.

The reason for this inconsistency is that neither the KAAB accreditation system nor the program curricula require a close link between these courses. Moreover, this missing link between theory courses and design studios in earlier and later years of study is also reflected in a learned design process that is generally not related to sustainability issues addressed in earlier courses. When students learn about sustainability issues during later study years, they generally lack the ability to consider sustainability issues in their own design work.

The basic problem here is that sustainability issues are not integrated into architectural design projects; rather, they remain an ancillary consideration. Therefore, we suggest consistently addressing SPCs from the first to the last study year, in both theory and practice-oriented courses. In order to facilitate such a progressive accumulation and integration of diverse and complex aspects of sustainability in studios, theory modules need to be concurrently offered during complex architectural project assignments that address sustainable design issues. Furthermore, projects need to become more complex in later years, in order to challenge students to enhance their previously gained knowledge and skills relating to sustainability. 


\subsection{Delayed Integration of Sustainability SPCs into Studios}

The results of this study suggest that SPC and accompanying type curricula have better potential for integrating sustainability issues than other curricula types. These Korean accompanying type curricula are comparable with the 'parallel-type' curricula found in European programs. This curriculum type is one of five paradigmatic curricular models put forth in the 'Sustainable Architecture Education White Paper' [13]. The other models are 'partially integrated', 'fully integrated', 'iterative', and 'elective/minor'. None of the five models is ideal regarding integrated sustainable architectural education, because each model has specific advantages and disadvantages [13].

This research finds that progressively addressing sustainability SPC content in studios during later years of study is consistent with both the increasing complexity of projects, and knowledge accumulated, in previous courses. However, when accumulated sustainability SPC credits from studios overlap with an uneven distribution or a delayed positioning of the sustainability core course, the risk of disconnection between theoretical and practical content becomes of real concern. Therefore, the authors suggest careful positioning and earlier distribution of sustainability core courses, accompanied by more robust communication of sustainability-related SPCs in studios.

The most frequent pattern of delayed integration is related to SPC 15 (integration of building systems in design). This deserves special attention, as building structure, envelope and mechanical and electrical service systems, among other building components, are closely related to sustainability issues. Since the sustainability issues related to these different building systems are introduced to students in separate sustainability core courses spanning several semesters, remembering and effectively utilizing this knowledge takes a long time. As evidence, if SPC 15 is introduced too late in the curriculum, students have fewer opportunities to develop an ability to integrate these issues in practice.

\subsection{Balance between the Environment, Culture and Economy}

Reviewing the eight sustainability-related SPCs defined by the KAAB has revealed a strong programmatic bias toward technology and the environment; whereas, not one SPC addresses culture and the economy. Furthermore, a substantial number of the programs almost exclusively based their training on environmental issues mentioned in the guidelines of SPC 15 (integration of building systems in design), SPC 21 (sustainable means of environmental control), SPC 22 (environmental control systems) and SPC 23 (building service systems). Additionally, these technologically oriented sustainability core courses were concentrated in the later years of curricula, and therefore fall short of creating a balanced education in sustainability.

This narrow, technologically focused scope of sustainability issues covered in Korean architectural programs neglects locally adaptive, passive, and other low-tech alternatives to energy efficient architectural design. This information has already been put forth by Rieh in 2002 [54]. Therefore, this study questioned the capability of the accrediting system to address such a holistic deficiency, especially given that this weakness is not unique to Korea. For example, in their analysis of U.S. programs, Iulo et al. found that a majority of discursive approaches at architecture schools are still focused on technology [52].

A complete education in sustainability is only possible when the three categories of sustainability-environmental, sociocultural and economic - are properly balanced. Architecture and urbanism are deeply related to the socioeconomic conditions of a particular time and place. With respect to the KAAB's incipient task of regional accreditation in the Asia-Pacific region, special attention to specific local and regional peculiarities is necessary. Therefore, the sustainability SPCs should undergo major revision, in order to create a meaningful international accrediting service that upholds substantial equivalency. 


\section{Conclusions}

This research analyzes the integration of sustainability into South Korean program curricula in response to the KAAB accrediting system. The accumulation of sustainability SPCs, with understanding as a learning goal in sustainability core courses and ability as a learning goal in studios, has been identified as a general issue.

Studios and sustainability core courses have been analyzed and compared in terms of the quantity and sequence of sustainability SPC accumulation, using data obtained from the architectural program reports of 48 programs. Four different curriculum typologies of sustainability core course and studio integration have been identified. These preceding type, accompanying type, following type and fluctuation type curricula could be clearly assigned to a total of 19 of the 48 programs analyzed. The remaining 29 programs did not fit clearly into any specific curriculum type. The preceding and accompanying type curricula were found to have better potential to integrate principles of sustainability, because the sequence of sustainability core courses and studios indicates balanced teaching of theoretical knowledge and its application in studios. In contrast, the other identified course types did not suggest a logical balance between sequences of sustainability core courses and studios. Therefore, following and fluctuation type curricula were regarded as more challenging for sufficient integration of theory and practice with respect to sustainable architecture.

These conclusions are cursory and limited in scope, because they are mainly based on the quantitative, and only to a minor extent on the qualitative analysis, of Korean programs. The curricula have been analyzed regarding sustainability SPCs, accumulated sustainability course credits, their assignment to different course types, and distribution during a 5-year study period. A detailed analysis of all courses addressing sustainability SPCs in most significant accredited programs, including course syllabi and course plans, would be required to understand more detailed information on how sustainability issues are addressed and integrated into the curricula of accredited architecture schools in South Korea. However, such a qualitative analysis would be very complex, and goes well beyond the scope of this research.

Another important finding is that the KAAB accreditation method is based on a clear division of SPCs into ability and understanding learning objectives, which are distributed mainly in studios or sustainability core courses, respectively. This radical division is a barrier to integrated sustainable architectural education, thereby limiting the integration of theory and practice, as well as the possibility of achieving a holistic sustainable education. An additional difficulty in integrating sustainable architectural education is the delayed introduction of sustainability issues in studio courses, in comparison to sustainability core courses, in a majority of the programs we analyzed.

Another important issue is the strong imbalance between environmental, sociocultural, and economic issues relating to sustainability. Korean programs accredited by the KAAB clearly focus on a technological approach and environmental issues, but are extremely deficient in addressing sociocultural and economic issues.

The results of this research identify advantages and disadvantages of sustainable architectural education in accredited Korean programs, and provide suggestions to enhance their planning. Furthermore, the findings open clear perspectives for revising the KAAB accrediting system, in order to improve the integration of sustainable architectural education into accredited programs. This improvement is particularly important in the context of the growing importance of sustainable development, both nationally and globally, as well as the growing influence of South Korea in the Asia-Pacific region and the incipient international accreditation service provided by the KAAB.

Supplementary Materials: The following are available online at www.mdpi.com/2071-1050/9/7/1121/s1.

Author Contributions: The authors contributed equally to the development of the research methods, literature review, analyses and evaluation of data, as well as the writing of this article.

Conflicts of Interest: The authors declare no conflict of interest. 


\section{Appendix A}

Table A1. Accumulated credits for eight sustainability SPCs of studios and sustainability core courses in 48 accredited universities in Korea.

\begin{tabular}{|c|c|c|c|c|}
\hline \multirow{2}{*}{$\begin{array}{l}\text { Program } \\
\text { Number }\end{array}$} & \multirow{2}{*}{ University } & \multicolumn{2}{|c|}{$\begin{array}{l}\text { Accumulated Sustainability } \\
\text { SPC Credits }\end{array}$} & \multirow{2}{*}{ University Website } \\
\hline & & Studios & $\begin{array}{l}\text { Sustainability } \\
\text { Core Courses }\end{array}$ & \\
\hline 1 & $\begin{array}{l}\text { Department of Architecture, } \\
\text { Kangwon National University }\end{array}$ & 8.36 & 13.25 & http:/ /architecture.kangwon.ac.kr(kr) \\
\hline 2 & $\begin{array}{l}\text { Department of Architecture, } \\
\text { Kyonggi University }\end{array}$ & 5.88 & 11.00 & $\begin{array}{l}\text { http:/ / www.kyonggi.ac.kr/curriculumEngSrv. } \\
\text { kgu?mzcode=K07M01000600\&orgCd=K010902 (en) }\end{array}$ \\
\hline 3 & $\begin{array}{l}\text { School of Architecture, } \\
\text { Kyungpook National } \\
\text { University }\end{array}$ & 9.90 & 7.50 & http:/ /arch.knu.ac.kr/ (kr) \\
\hline 4 & $\begin{array}{l}\text { School of Architecture, } \\
\text { Gyeongsang National } \\
\text { University }\end{array}$ & 11.25 & 4.58 & $\begin{array}{l}\text { http: } \\
\text { //arch.gnu.ac.kr/archit/sub.do?mCode=MN0029 } \\
\text { (kr) }\end{array}$ \\
\hline 7 & $\begin{array}{l}\text { Department of Architectural } \\
\text { Design, Catholic Kwandong } \\
\text { University }\end{array}$ & 8.95 & 9.75 & $\begin{array}{l}\text { http:/ / www.cku.ac.kr/mbshome/mbs/CKU/ } \\
\text { download/engineer_arch.hwp (kr) }\end{array}$ \\
\hline 8 & $\begin{array}{l}\text { Department of Architecture, } \\
\text { Kwangwoon University }\end{array}$ & 9.50 & 10.75 & $\begin{array}{l}\text { https: } \\
\text { //www.kw.ac.kr/en/univ/engineering04_5.do (en) }\end{array}$ \\
\hline 9 & $\begin{array}{l}\text { Division of Architecture, } \\
\text { Kongju National University }\end{array}$ & 8.89 & 10.75 & $\begin{array}{l}\text { http://archi.kongju.ac.kr/edu/02_02_popup.asp } \\
\text { (kr) }\end{array}$ \\
\hline 10 & $\begin{array}{l}\text { College of Architecture, } \\
\text { Kookmin University }\end{array}$ & 8.33 & 15.00 & $\begin{array}{l}\text { http: } \\
\text { //archi.kookmin.ac.kr/site/en/currculum.htm (en) }\end{array}$ \\
\hline 12 & $\begin{array}{l}\text { School of Architecture, Catholic } \\
\text { University of Daegu }\end{array}$ & 10.70 & 14.17 & http://dept.cu.ac.kr/user/cuarchi/ (kr) \\
\hline 13 & $\begin{array}{l}\text { Division of Architecture and } \\
\text { Civil Engineering }\end{array}$ & 25.33 & 6.00 & $\begin{array}{l}\text { http: } \\
\text { / / uni.dongseo.ac.kr/civil/?pCode=1278908885 (kr) }\end{array}$ \\
\hline 14 & $\begin{array}{l}\text { Department of Architecture, } \\
\text { Dong-A University }\end{array}$ & 13.20 & 12.56 & http:/ /arch.donga.ac.kr/arch/4648/subview.do (kr) \\
\hline 15 & $\begin{array}{l}\text { Department of Architecture, } \\
\text { Dong-Eui University }\end{array}$ & 10.75 & 10.00 & http:/ / deuproarchi.deu.ac.kr/curriculum (kr) \\
\hline 16 & $\begin{array}{l}\text { Department of Architecture, } \\
\text { Mokpo National University }\end{array}$ & 8.59 & 12.40 & $\begin{array}{l}\text { http://doa.mokpo.ac.kr/index.9is?contentUid= } \\
\text { 4a94e39d50f636120150fac9d70e01fc\#list_3_1 (kr) }\end{array}$ \\
\hline 17 & $\begin{array}{l}\text { College of Architecture, } \\
\text { Myungji University }\end{array}$ & 3.30 & 8.55 & http:/ /arch.mju.ac.kr/camu/202.php (kr) \\
\hline 18 & $\begin{array}{l}\text { Department of Architecture, } \\
\text { Pukyung National University }\end{array}$ & 10.00 & 10.25 & \\
\hline 19 & $\begin{array}{l}\text { Department of Architecture, } \\
\text { Pusan National University }\end{array}$ & 10.84 & 7.95 & $\begin{array}{l}\text { http:/ / uwcms.pusan.ac.kr/user/34320aeng/ } \\
\text { download/교육과정표/2013\%20Department } \\
\% 20 \text { of\%20Architecture\%20Curriculum.pdf (kr) }\end{array}$ \\
\hline 20 & $\begin{array}{l}\text { School of Architecture, Seoul } \\
\text { National University of Science } \\
\text { and Technology }\end{array}$ & 9.12 & 9.75 & $\begin{array}{l}\text { http:/ /archidesign.seoultech.ac.kr/curriculum/ } \\
\text { certification_course_for_architecture_/ (en) }{ }^{*}\end{array}$ \\
\hline
\end{tabular}


Table A1. Cont.

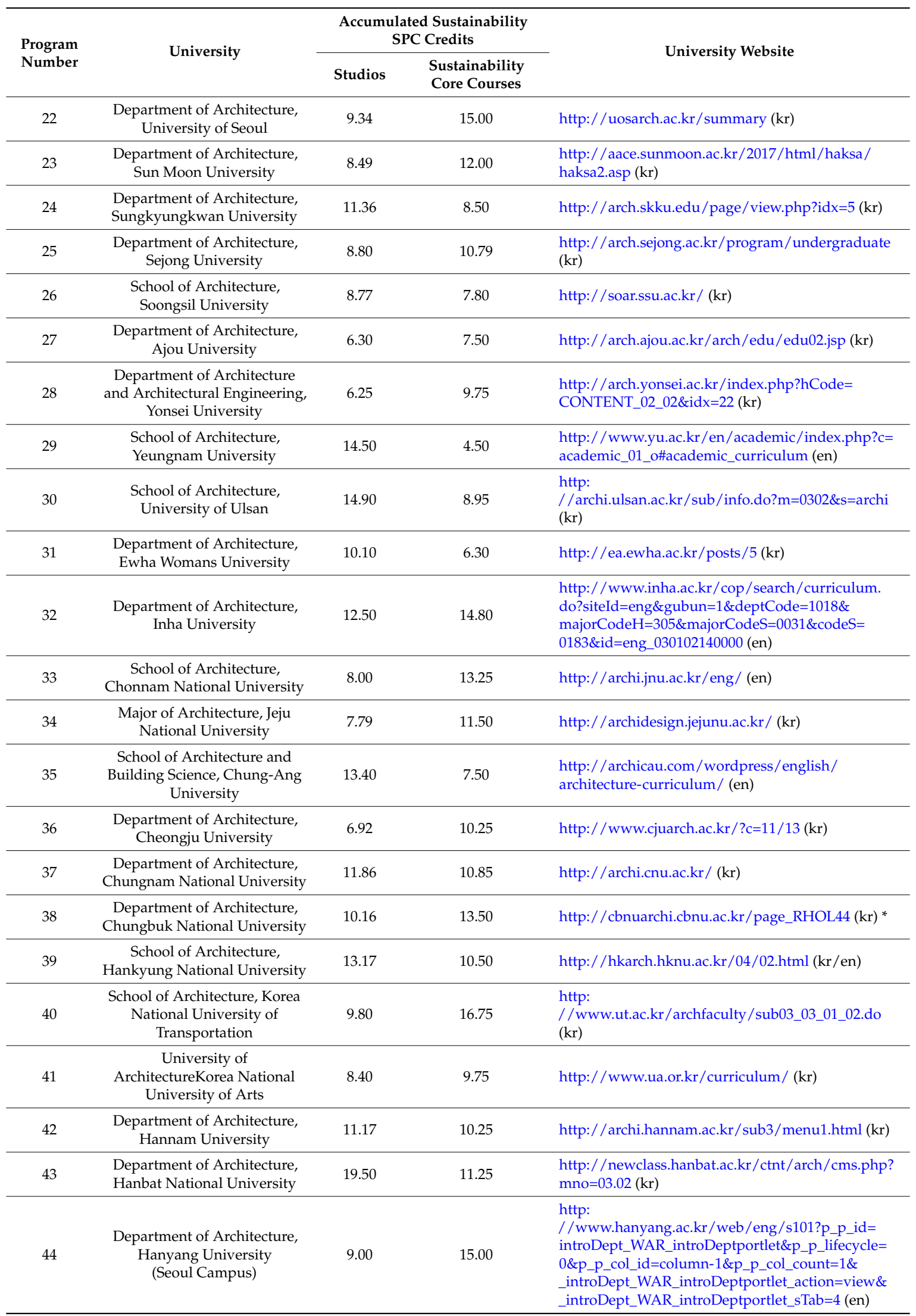


Table A1. Cont.

\begin{tabular}{|c|c|c|c|c|}
\hline \multirow{2}{*}{$\begin{array}{l}\text { Program } \\
\text { Number }\end{array}$} & \multirow{2}{*}{ University } & \multicolumn{2}{|c|}{$\begin{array}{l}\text { Accumulated Sustainability } \\
\text { SPC Credits }\end{array}$} & \multirow{2}{*}{ University Website } \\
\hline & & Studios & $\begin{array}{l}\text { Sustainability } \\
\text { Core Courses }\end{array}$ & \\
\hline 45 & $\begin{array}{l}\text { Department of Architecture, } \\
\text { Hanyang University } \\
\text { (Erica Campus) }\end{array}$ & 11.59 & 12.54 & http://www.hanyang.ac.kr/web/eng/e1011 (en) \\
\hline 46 & $\begin{array}{l}\text { Major of Architecture, } \\
\text { Hoseo University }\end{array}$ & 10.30 & 7.50 & $\begin{array}{l}\text { http: } \\
\text { //arch.hoseo.ac.kr/CmsHome/academic_01.eznic } \\
\text { (kr) }\end{array}$ \\
\hline 47 & $\begin{array}{l}\text { School of Architecture, Hongik } \\
\text { University (Seoul Campus) }\end{array}$ & 6.00 & 9.50 & http://arch.hongik.ac.kr/ (kr) \\
\hline 48 & $\begin{array}{l}\text { School of Architecture, Hongik } \\
\text { University (Sejong Campus) }\end{array}$ & 6.70 & 8.20 & $\begin{array}{l}\text { http:/ /hiarc.hongik.ac.kr/html/?pmode= } \\
\text { subpage\&MMC_pid=203\&spSeq=16 (kr) }\end{array}$ \\
\hline
\end{tabular}

* Curriculum and Student Performance Criteria Matrix.

\section{References}

1. Jabareen, Y. A New Conceptual Framework for Sustainable Development. Environ. Dev. Sustain. 2008, 10, 179-192. [CrossRef]

2. Berke, P.R.; Kartez, J. Sustainable Development as a Guide to Community Land Use Policy; Lincoln Institute of Land Policy: Cambridge, MA, USA, 1995.

3. Healey, P.; Shaw, T. Planners, plans and sustainable development. Reg. Stud. 1993, 27, 769-776. [CrossRef]

4. Meadows, D.H.; Meadows, D.L.; Randers, J. Beyond the limits: Confronting global collapse, envisioning a sustainable future. Post Mills Vt. Chelsea Green Publ. Co. 1992, xix, 300.

5. Robinson, J.; Tinker, J. Reconciling ecological, economic and social imperatives: A new conceptual framework. In Surviving Globalism; Palgrave: Macmillan, UK, 1997; pp. 71-94.

6. Scruggs, P. Guidelines for State Level Sustainable Development; Center for Policy Alternatives: Ottawa, ON, Canada, 1993.

7. KAAB. Korea Architectural Accrediting Board, KAAB Conditions \& Procedures for Professional Degree programs in Architecture, 2013 Edition. 2013. Available online: http:/ /www.kaab.or.kr/download/kaab_ 2013_c_and_p.Pdf (accessed on 11 February 2016).

8. Canizaro, V.; Tanzer, K. Environmental Architectures and Sustainability: A Taxonomy of Tactics. J. Archit. Educ. 2007, 60, 4-14. [CrossRef]

9. European Parliament. Directive 2010/31/EU of the European Parliament and of the Council of 19 May 2010 on the Energy Performance of Buildings. Off. J. Eur. Union 2010, 153, 13-35.

10. EDUCATE. Education for Sustainable Environmental Design: The EducatePproject, Summary of Results; University of Nottingham: Nottingham, UK, 2012.

11. Gould, K.; Hosey, L. Ecology \& Design: Ecological Literacy in Architecture Education; The American Institute of Architects: Washington, DC, USA, 2006.

12. Boyer, E.L.; Mitgang, L.D. Building Community: A New Future for Architecture Education and Practice: A Special Report; Carnegie Foundation for the Advancement of Teaching: Princeton, NJ, USA, 1996.

13. Trachte, S.; De Herde, A.; López de Asiaín, M.; Burgos, C.E.; Altomonte, S.; Gobson, A. Sustainable Architectural Education White Paper; Department of Architecture and Built Environment, University of Nottingham: Nottingham, UK, 2012.

14. UIA. UIA Accord on Recommended International Standards of Professionalism in Architectural Practice; UIA Professional Practice Program Joint Secretariat: Durban, South Africa, 2014.

15. Attoe, W.; Mugerauer, R. Excellent studio Teaching in Architecture. Stud. High. Educ. 1991, 16, 41-50. [CrossRef]

16. EDUCATE. Framework for Curriculum Development; The University of Nottingham: Nottingham, UK, 2012.

17. Kishnani, N. Greening Asia: Emerging Principles for Sustainable Architecture; BCI Asia: Hong Kong, China, 2012.

18. Hamiti, S.; Wydler, H. Supporting the Integration of Sustainability into Higher Education Curricula-A Case Study from Switzerland. Sustainability 2014, 6, 3291-3300. [CrossRef] 
19. Alvarez, S.P.; Lee, K.; Park, J.; Rieh, S.Y. A Comparative Study on Sustainability in Architectural Education in Asia-With a Focus on Professional Degree Curricula. Sustainability 2016, 8, 290. [CrossRef]

20. Oxford University. English Oxford Living Dictionaries. Available online: https://en.oxforddictionaries.com/ (accessed on 2 June 2017).

21. Vitruvius. The Ten Books on Architecture, Digital Edition ed; Project Gutenberg (eBook): Salt Lake City, UT, USA, 2006.

22. Rush, R.D. The Building Systems Integration Handbook; American Institute of Architects: Washington, DC, USA; Butterworth-Heinemann: Oxford, UK, 1986.

23. Bachman, L.R. Integrated buildings: The Systems Basis of Architecture; John Wiley \& Sons: New York, NY, USA, 2004; Volume 9.

24. Keeler, M.; Vaidya, P. Fundamentals of Integrated Design for Sustainable Building; John Wiley \& Sons: New York, NY, USA, 2016.

25. Ledewitz, S. Models of Design in studio Teaching. J. Archit. Educ. 1985, 38, 2-8. [CrossRef]

26. Douvlou, E. Effective Teaching and Learning: Integrating Problem-Based Learning in the Teaching of Sustainable Design (1998). CEBE Trans. 2006, 3, 23-37. [CrossRef]

27. Steinemann, A. Implementing Sustainable Development Through Problem-Based Learning: Pedagogy and Practice. J. Prof. Issues Eng. Educ. Pract. 2003, 129, 216-224. [CrossRef]

28. Brundiers, K.; Wiek, A. Do we Teach what we Preach? An International Comparison of Problem-And Project-Based Learning Courses in Sustainability. Sustainability 2013, 5, 1725-1746. [CrossRef]

29. Clark, R.; Kirschner, P.A.; Sweller, J. Why Minimal Guidance During Instruction Does not Work: An Analysis of the Failure of Constructivist, Discovery, Problem-Based, Experiential, and Inquiry-Based Teaching. Educ. Psychol. 2006, 41, 75-86.

30. UNESCO-UIA. UNESCO-UIA Validation System for Architectural Education; International Union of Architects (UIA): Paris, France, 2002; p. 31.

31. Homepage of the NAAB (National Architectural Accrediting Board). International Architecture Programs "Substantially Equivalent". Available online: http://www.naab.org/international/substantial-equivalency/ (accessed on 17 March 2017).

32. Guadet, J.; Pascal, J.L. Eléments et Théorie de L'architecture, 3rd ed.; Librarie de la Construction Moderne: Paris, France, 1909; Volume 1, p. 661.

33. Hung, W. Theory to Reality: A Few Issues in Implementing Problem-Based Learning. Educ. Technol. Res. Dev. 2011, 59, 529-552. [CrossRef]

34. Schmidt, H.G.; Rotgans, J.I.; Yew, E.H. The Process of Problem-Based Learning: What Works and Why. Med. Educ. 2011, 45, 792-806. [CrossRef] [PubMed]

35. The Camberra Accord Homepage. Available online: http://www.canberraaccord.org/ (accessed on 27 February 2017).

36. Canberra Accord Rules and Procedures. 2013. Available online: http://www.canberraaccord.org/Public Documents $/$ streamfile.aspx?name=CA..Rules+and+Procedures+FINAL+EDITION+-+archived.pdf\& path=Canberra+Accord+Rules+and+Procedures $\% 5 c$ (accessed on 20 June 2017).

37. Camberra Accord List of Signatories. Available online: http:/ /www.canberraaccord.org/signatoriespublic/ home.aspx (accessed on 17 March 2017).

38. The Homepage of KAAB (Eanglish Version). Available online: http://eng.kaab.or.kr/About/about_01 (accessed on 28 Febuary 2017).

39. KAAB Accredited programs List, 2016 (English Version). Available online: http://eng.kaab.or.kr/programs / programs_01 (accessed on 28 Febuary 2017).

40. KAAB List of Accredited programs 2016-2017 (Korean Version). Available online: http://kaab.or.kr/html/ sub04_2.asp (accessed on 28 February 2017).

41. Korea Architectural Accrediting Board. KAAB International Service Policy for Professional Degree Programs in Architecture; Korea Architectural Accrediting Board: Seoul, Korea, 2016; p. 11.

42. Quarrie, J. Earth Summit'92: The United Nations Conference on Environment and Development, Rio de Janeiro, Brazil, 1992; Regency Press Corporation Ltd.: London, UK, 1992.

43. Logan, W.S. The Disappearing Asian City: Protecting Asia's Urban Heritage in a Globalizing World; Oxford University Press: Oxford, UK, 2002. 
44. Ignatieva, M. Design and Future of Urban Biodiversity. In Urban Biodiversity and Design; Muller, N., Werner, P., Kelcey, J.G., Eds.; John Wiley \& Sons: New York, NY, USA, 2010; pp. 118-144.

45. Wright, J. Introducing Sustainability into the Architecture Curriculum in the United States. Int. J. Sustain. High. Educ. 2003, 4, 100-105. [CrossRef]

46. Warburton, K. Deep Learning and Education for Sustainability. Int. J. Sustain. High. Educ. 2003, 4, 44-56. [CrossRef]

47. Khan, A.Z.; Vandevyvere, H.; Allacker, K. Design for the Ecological Age: Rethinking the Role of Sustainability in Architectural Education. J. Archit. Educ. 2013, 67, 175-185. [CrossRef]

48. Ostwald, M.J.; Williams, A.; Learning, A.; Council, T. Understanding Architectural Education in Australasia; Australian Learning and Teaching Council: Sydney, Australia, 2008.

49. Altomonte, S.; Rutherford, P.; Wilson, R. Mapping the Way Forward: Education for Sustainability in Architecture and Urban Design. Corp. Soc. Responsib. Environ. Manag. 2014, 21, 143-154. [CrossRef]

50. Salama, A.; Amir, A. Paradigmatic Trends in Arab Architectural Education: Impacts and Challenges; Paper Intended for Publication and Presentation at the International Congress of Architecture; The International Union of Architects-UIA: Istanbul, Turkey, 2005.

51. Ismail, M.A.; Keumala, N.; Dabdoob, R.M. Review on Integrating Sustainability Knowledge into Architectural Education: Practice in the UK and the USA. J. Clean. Prod. 2017, 140, 1542-1552. [CrossRef]

52. Domenica Iulo, L.; Gorby, C.; Poerschke, U.; Nickolas Kalisperis, L.; Woollen, M. Environmentally Conscious Design-Educating Future Architects. Int. J. Sustain. High. Educ. 2013, 14, 434-448. [CrossRef]

53. Shari, Z.; Jaafar, M.F.Z. Towards a More Sustainable Architectural Education in Malaysia. ALAM CIPTA Int. J. Sustain. Trop. Des. Res. Pract. 2006, 1, 57-64.

54. Rieh, S.Y. Survey on the Architectural Design Education in Korea from the View of International Education Criteria for Architecture-With Focus on the Studio Assignment of Schools in Seoul. J. Archit. Inst. Korea (Plan. Des.) 2002, 164, 53-60.

55. Lee, K.S.; Geon, K.R.; Yoo, D. A Study on Integrating Sustainability into Architectural Education Curriculum in Korea. J. Archit. Inst. Korea 2012, 28, 127-138. 